\begin{tabular}{|c|l|}
\hline Title & $\begin{array}{l}\text { Mobilization and speciation of arsenic from hydrothermally altered rock containing cal cite and pyrite under anoxic } \\
\text { conditions }\end{array}$ \\
\hline Author(s) & Tabelin, Carlito Baltazar; Igarashi, Toshifumi; Y oneda, Tetsuro \\
\hline Citation & $\begin{array}{l}\text { A pplied Geochemistry, 27(12), 2300-2314 } \\
\text { https://doi.org/10.1016/.apgeochem.2012.07.020 }\end{array}$ \\
\hline Issue Date & $2012-12$ \\
\hline Doc URL & http://hdl.handle.net/2115/50830 \\
\hline Type & article (author version) \\
\hline Additional Information & There are other files related to this item in HUSCAP. Check the above URL. \\
\hline File Information & AG27-12_2300-2314.pdf \\
\hline
\end{tabular}

Instructions for use 


\title{
Mobilization and speciation of arsenic from hydrothermally altered rock containing calcite and pyrite under anoxic conditions
}

\author{
Carlito Baltazar Tabelin ${ }^{*}$, Toshifumi Igarashi ${ }^{\mathrm{b}}$ and Tetsuro Yoneda ${ }^{\mathrm{a}}$ \\ ${ }^{a}$ Laboratory of Soil Environment Engineering, Faculty of Engineering, Hokkaido University, Sapporo 060-8628, \\ JAPAN \\ ${ }^{\mathrm{b}}$ Laboratory of Groundwater and Mass Transport, Faculty of Engineering, Hokkaido University, Sapporo 060- \\ 8628, JAPAN \\ E-mails: carlito@trans-er.eng.hokudai.ac.jp, tosifumi@eng.hokudai.ac.jp and yonet@eng.hokudai.ac.jp
}

\begin{abstract}
The effects of water residence time and anoxic conditions on the mobilization and speciation of arsenic (As) in a calcite- and pyrite-bearing altered rock excavated during a road-tunnel project has been evaluated using batch and column laboratory experiments. Higher infiltration rates (i.e., shorter water residence times) enhanced the leaching of As due to the higher $\mathrm{pH}$ values of the effluents and more rapid transport of dissolved As through the columns. The concentration of As in the effluent also increased under anoxic conditions regardless of the water residence time. This enhanced leaching of As under anoxic conditions could be attributed to a significant $\mathrm{pH}$ increase and decreased Fe oxyhydroxides/oxides precipitation compared to similar experiments done under ambient conditions. Processes that controlled the evolution of $\mathrm{pH}$ and the temporal release mechanisms of As under anoxic conditions were identical to those previously observed under ambient conditions: the dissolution of soluble phases, pyrite oxidation, co-precipitation and/or adsorption/desorption reactions. Speciation of As in the column experiments could partly be attributed to the $\mathrm{pH}$-dependent adsorption of As species onto Fe oxyhydroxides/oxides precipitates. Moreover, apparent equilibriums of the total As and arsenite (As[III]) concentrations were delayed under anoxic conditions in both batch and column experiments.
\end{abstract}

Keywords: Leaching; speciation; arsenic; anoxic condition; column experiments

*Corresponding author: Tel: +81-11-706-6311 Fax: +81-11-706-6308

email: carlito@ trans-er.eng.hokudai.ac.jp 


\section{INTRODUCTION}

Arsenic (As) contamination of soil and groundwater from natural or anthropogenic sources is a serious problem encountered in many countries around the world that is affecting millions of people (Acharyya et al. 2000; Akai et al., 2004; Das et al., 1996; Dowling et al., 2002; Nickson et al., 2000). Arsenic is a toxic trace element that is ubiquitous in nature, and is usually concentrated in mineral sulfide ore bodies (Fleet et al., 1989; Huston et al., 1995; Smedley and Kinniburgh, 2002). Serious health problems like arsenicosis, keratosis and certain types of cancers (e.g., skin, lungs, liver, bladder and kidneys) have been linked to the chronic intake of this element through contaminated drinking water sources (Cebrian et al., 1983; Chakraborty and Saha, 1987; Chen et al., 1985; Chen et al., 1992; O’Day et al., 2004; Sengupta, 2002; Smith et al., 1992; Tseng et al., 1968; Zaldivar, 1974).

Recent road and tunnel construction projects in Japan have excavated rocks with elevated contents of hazardous elements like As, lead $(\mathrm{Pb})$, boron $(\mathrm{B})$, chromium $(\mathrm{Cr})$ and selenium $(\mathrm{Se})$. These rocks contain abnormally high amounts of these hazardous elements mainly because of hydrothermal alteration. This is to be expected because Japan is located in the Pacific ring of fire known for its active faults and volcanoes. Rocks that have been altered by hydrothermal fluids/solutions are collectively termed hydrothermally altered rocks, which have varying chemical and mineralogical properties depending on the nature and extent of their alterations as well as the inherent physical and chemical properties of the hydrothermal fluid (Pirajno, 2009). Excavated hydrothermally altered rocks are therefore potential sources of soil and groundwater contamination if not disposed of properly. Hydrothermally altered rocks have been extensively studied but mostly in the context of ore formation and characterization (Aiuppa et al., 2006; Allen and Hahn, 1994; Halbach et al., 1993; Horton et al., 2001; Huston et al., 1995; Ostwald 
and England, 1977). In addition, several authors have examined the geochemistry of toxic elements, such as As and some heavy metals, in contact with hydrothermally altered rocks at mine pit lakes (Davis and Ashenberg, 1989; Davis et al., 2006; Eary, 1998; Levy et al., 1997; Savage et al., 2009; Tempel et al., 2000). However, very few have studied the leaching behaviors and release mechanisms of these toxic elements from excavated altered rocks.

The authors have identified several important factors controlling the release of $\mathrm{As}$ and $\mathrm{Pb}$ from altered rocks and have proposed several mechanisms in their previous papers (Igarashi $e t$ al., 2008; Tabelin and Igarashi, 2009; Tabelin et al., 2010; Tabelin et al., 2012a). However, most of the data in these studies were obtained using batch experiments close to equilibrium conditions. Although these data are useful as a reference, they provide little information about the temporal and spatial mechanisms controlling the movement of these toxic elements that is of primary importance in the disposal of these hazardous waste rocks. The most recent work of the authors had partly tackled this problem utilizing calcite-pyrite-bearing altered rock in laboratory column experiments under ambient conditions (Tabelin et al., 2012b). There were indeed temporal and spatial As release mechanisms from these sources. In addition, speciation of As was an important factor that influenced the release mechanisms especially during the early part of the experiments when most of the leaching took place (Tabelin et al., 2012b). Since the authors' previous column experiments were limited only to ambient conditions, the effects of atmospheric $\mathrm{O}_{2}$ and $\mathrm{CO}_{2}$ and water residence time on these release mechanisms still remain unclear. This is because changes in the water residence time (i.e., infiltration rate) under ambient conditions also caused variations in the concentrations of dissolved gases in the pore water (Tabelin et al., 2012b). Thus, it was speculated from these previous results that gaseous $\mathrm{O}_{2}$ and 
$\mathrm{CO}_{2}$ probably played a greater role in the release of As than was previously thought (Tabelin et al., 2012b).

This study aims to understand the effects of anoxic conditions and water residence time on the mobilization and speciation of As from calcite-pyrite-bearing altered rock producing leachates with slightly alkaline $\mathrm{pH}$. Effects of these parameters on the release of As are important especially during disposal because seasonal changes and other environmental factors experienced in an actual field setting could cause variable infiltration rates and oxic-anoxic conditions. In addition, this study would elucidate the speciation of As under anoxic conditions using batch and column experiments, and examine the important minerals found in the altered rock using microscopic analysis after the column experiments. Finally, geochemical modeling would be utilized to aid in the understanding of the processes that influence As release and speciation from the calcite-pyrite-bearing altered rock under anoxic conditions. This study is significant because it would help answer lingering questions about the importance of atmospheric gases and water residence time in the release of As, and provide a more accurate explanation of the mechanisms involved in its mobilization and speciation from altered rocks under slightly alkaline $\mathrm{pH}$ conditions.

\section{MATERIALS AND METHODS}

\subsection{Rock sample and anoxic conditions}

The hydrothermally altered rock used in the experiments was obtained from a road-tunnel project constructed on the island of Hokkaido, Japan, which is the same altered rock sample utilized in the previous study of the authors (Tabelin et al., 2012b). This excavated rock is mainly composed of hydrothermally altered slate, sandstone and mudstone from the Hidaka 
metamorphic belt and a detailed discussion of the geology, alteration and characterization of the tunnel area is found elsewhere (Takahashi et al., 2011). The sample used in this study is a mixture of altered and unaltered rocks collected from the bulk excavated rock, which is primarily composed of silicate minerals (i.e., quartz and plagioclase) with calcite, kaolinite and chlorite as minor minerals and trace amounts of pyrite (Tabelin et al., 2012b). Arsenic content of the sample is $23.6 \mathrm{mg} / \mathrm{kg}$, with low sulfur content of $0.20 \%$ by weight (Tabelin et al., 2012b). Pyrites in hydrothermally altered rocks contain substantial amounts of As, sometimes reaching $1.07 \mathrm{wt} \%$ (Tabelin et al., 2012a). The sample also contains trace amounts of Mn and organic matter at $0.07 \%$ by weight as $\mathrm{MnO}$ and $0.23 \%$ by weight as organic $\mathrm{C}$. In the bulk excavated rock used in this study, mineral phases of As like arsenopyrite were not detected and pyrite was only found in trace amounts. Because of this, sequential extraction was conducted to identify the important solid phases incorporating As in the rock. The majority of As was found with sulfides at $55.2 \%$ of the total As content of the rock (Tabelin et al., 2012b). Significant amounts were also found in the exchangeable fraction (17.9\%), with carbonates $(2.3 \%)$ and with the reducible fraction (i.e., Fe-Mn oxides) (2.4\%). The remainder is associated with the crystalline/residual phases that are resistant to leaching under normal geological conditions. In addition, results of particle size distribution analysis of the $<2 \mathrm{~mm}$ fraction categorized this sample as clayey sand, which is a mixture of $70.4 \%$ sand, $22.3 \%$ silt and $7.3 \%$ clay (Tabelin et al., 2012b). The specific gravity (S) of the sample was measured using a pycnometer while its water content (w) was determined by gravimetry. The measured values of $\mathrm{S}$ and $\mathrm{w}$ are 2.731 and $0.5 \mathrm{wt} \%$, respectively. The rock sample used in both the batch and column experiments was taken from this $<2 \mathrm{~mm}$ fraction. All experiments were conducted inside a stainless steel glove box under 100\% argon (Ar) gas. This glove box has two chambers: the main chamber for the experiment and a smaller 
chamber for the introduction of needed materials. Each of these chambers can be individually controlled from the outside. Materials were introduced into the main chamber through the smaller chamber after the elimination of all gases using a vacuum pump. After this, $100 \%$ Ar gas was introduced into the small chamber before transferring the materials into the main chamber for the experiments. The deionized water $(18 \mathrm{M} \Omega \cdot \mathrm{cm})$ used was obtained from a Millipore MilliRx $12 \alpha$ system (Millipore Corporation, USA). Residual dissolved gases in the deionized water were removed in the small chamber by leaving the vacuum pump running for ca. 15 minutes after reaching vacuum conditions, which resulted in the vigorous "boiling" of the solution and expulsion of dissolved gases. Deionized water initially has a $\mathrm{pH}$ of 6.4 , but increased to 7.4 after the removal of dissolved gases, which indicates that dissolved $\mathrm{CO}_{2}$ was removed together with dissolved $\mathrm{O}_{2}(\mathrm{DO})$, resulting in the observed $\mathrm{pH}$ increase. Gaseous $\mathrm{O}_{2}$ inside the main chamber was monitored using an oxygen detector (Ox-01, Riken Keiki, Japan) while the DO concentrations of the deionized water, leachates and effluents were checked using an oxygen probe (Water Checker IWC-5, Sansyo Corporation, Taiwan). In both batch and column experiments, gaseous $\mathrm{O}_{2}$ in the glove box as well as DO of the deionized water, leachates and effluents were negligible $(\approx 0 \%)$.

\subsection{Batch leaching experiments}

The batch leaching experiments were conducted using solid-liquid mass ratios of 1:5 (30 g of rock/150 $\mathrm{ml}$ of deionized water) and 1:10 (15 $\mathrm{g}$ of rock/150 $\mathrm{ml}$ of deionized water) at mixing intervals of $0.5,2,6,10$ and 24 hours inside the glove box under anoxic conditions. The $\mathrm{pH}$ and Eh of suspensions were measured after the predetermined mixing time. The leachates were obtained by filtration of the suspensions through Millex ${ }^{\circledR}$ sterile membrane filters (Millipore 
Corporation, USA) inside the glove box. The leachates were then taken out of the glove box and stored at $6^{\circ} \mathrm{C}$ prior to the chemical analysis.

\subsection{Column experiments}

\subsubsection{Apparatus and initial parameters}

The column apparatus used in this study is identical to that outlined in the previous paper of the authors (Tabelin et al., 2012b), which is made of PVC tubes with inner diameters of $52 \mathrm{~mm}$ mounted on top of a steel stand with each stand accommodating three columns. Three columns were constructed inside the glove box under $100 \%$ Ar gas to prevent any residual $\mathrm{O}_{2}$ and $\mathrm{CO}_{2}$ in the columns prior to the experiments. The thickness of the rock bed and the degree of compaction was standardized in all columns by compacting $344 \mathrm{~g}$ of sample to $100 \mathrm{~mm}$. This procedure was repeated until a thickness of $200 \mathrm{~mm}$ was achieved.

\subsubsection{Influent parameters and effluent collection}

Under anoxic conditions, the infiltration rate was varied while maintaining a uniform rock bed thickness. Degassed deionized water was introduced once a week on top of the columns via rainfall simulators at amounts equivalent to 20,40 and $80 \mathrm{~mm} /$ week of rainfall and allowed to flow by gravity. The effluents were collected after about 2 days, and filtered through $0.45 \mu \mathrm{m}$ Millex ${ }^{\circledR}$ filters after the measurements of $\mathrm{pH}$, Eh and electrical conductivity (EC). The filtrates were put into propylene bottles for storage. All of these steps were done inside the glove box to prevent any interaction with atmospheric $\mathrm{O}_{2}$ and $\mathrm{CO}_{2}$. The filtered effluent samples were then taken out of the glove box and stored at $6^{\circ} \mathrm{C}$ prior to the chemical analyses. Details of the column experimental conditions and setup are summarized in Table 1. For the remainder of this paper, the columns are referred to as follows: 
- Column with rock bed thickness of $200 \mathrm{~mm}$ and infiltration rate of $20 \mathrm{~mm} / \mathrm{week}$ is called case1-anoxic.

- Column with rock bed thickness of $200 \mathrm{~mm}$ and infiltration rate of $40 \mathrm{~mm} /$ week is referred to as case 2-anoxic.

- Column with rock bed thickness of $200 \mathrm{~mm}$ and infiltration rate of $80 \mathrm{~mm} / \mathrm{week}$ is called case 3-anoxic.

After 59 weeks, spike and tracer tests were conducted in all three columns. The tracer used was bromide $\left(\mathrm{Br}^{-}\right)$ion and was prepared using reagent grade potassium bromide $(\mathrm{KBr})$ powders (Wako Pure Chemical Industries Ltd., Japan). Spike tests were done using As[V] or As[III] solutions: As[III] was introduced into case 1-anoxic while As[V] was used in cases 2- and 3anoxic. The solutions of $\mathrm{As}[\mathrm{V}]$ and $\mathrm{As}[\mathrm{III}]$ were prepared using reagent grade $\mathrm{Na}_{2} \mathrm{HAsO}_{4} \cdot 7 \mathrm{H}_{2} \mathrm{O}$ powders and 1,000 mg/L As[III] standard solutions for atomic absorption spectrometry, respectively (Wako Pure Chemical Industries Ltd., Japan). The chemical properties of the influent solutions used in the column experiments are listed in Table 2. The pore volume (PV) in each column was calculated from the American Society for Testing Materials (1989), which is also found in the previous work of the authors (Tabelin et al., 2012b).

The hydrothermally altered rock in the columns underwent additional compaction after the first PV of effluent collection. The thickness of the rock beds decreased by ca. $5 \mathrm{~mm}$ in all cases and remained virtually constant until the end of the experiment. These changes observed after the first PV were also incorporated in our calculations (Table 1).

\subsubsection{Post-experimental characterization}

The column experiments were terminated after 90 weeks and all columns were sectioned. Each section was ca. $25 \mathrm{~mm}$ thick and pore waters from these sections were collected using a 
centrifuge. Microscopic analysis was also done on the bottom section collected from case 2anoxic using a scanning electron microscope (SEM) (SSX-550, Shimadzu Corporation, Japan) with energy dispersive X-ray spectroscopy (EDS) capability to identify important minerals that influenced As leaching like Fe sulfides and oxyhydroxides/oxides. The SEM was operated using $30.0 \mathrm{kV}$ accelerating voltage while the EDS maps were taken at 13,000 cps with 1,000 ms time constant.

\subsection{Chemical Analysis}

Arsenic concentration in the leachate/effluent samples and pore water greater than $100 \mu \mathrm{g} / \mathrm{L}$ was analyzed using an inductively coupled plasma atomic emission spectrometer (ICP-AES) (ICPE 9000, Shimadzu Corporation, Japan). Liquid samples with low As concentrations ( $<100 \mu \mathrm{g} / \mathrm{L})$ were first pretreated and then analyzed using the hydride generation process coupled with the ICP-AES. For the pre-treatment, $30 \mathrm{ml}$ of the sample was mixed with $15 \mathrm{ml}$ of $12 \mathrm{M}$ hydrochloric acid ( $\mathrm{HCl}$ ), $2 \mathrm{ml}$ of $20 \%$ potassium iodide (KI) solution, $1 \mathrm{ml}$ of $10 \%$ ascorbic acid solution and diluted with deionized water to $50 \mathrm{ml}$. All chemicals used in the pre-treatment are reagent grade. Sulfur in the leachates/effluents was predominantly in the form of sulfate $\left(\mathrm{SO}_{4}{ }^{2-}\right)$ based on the results of anion chromatography (ICS - 1000, Dionex Corporation, USA) of the leachate samples and the first 20 effluent samples collected from the columns. Thus, for faster and easier determination of $\mathrm{SO}_{4}{ }^{2-}$, the ICP-AES was used later on in the study. Coexisting ions like $\mathrm{Ca}, \mathrm{Si}, \mathrm{Al}$ and $\mathrm{Fe}$ with concentrations greater than $0.1 \mathrm{mg} / \mathrm{L}$ were also analyzed using the ICP-AES without any attachment, but lower concentrations $(<0.1 \mathrm{mg} / \mathrm{L})$ were determined using an ultrasonic aerosol generator attached to the ICP-AES. The standard ICP-AES method (i.e., without attachment) has a margin of error of ca. $2-3 \%$ while more sensitive hydride generation and ultrasonic aerosol generator methods have uncertainties of ca. 5\%. The detection limits of 
the standard ICP-AES method for $\mathrm{Ca}, \mathrm{Fe}, \mathrm{S}, \mathrm{As}, \mathrm{Al}$ and $\mathrm{Si}$ are approximately 0.1, 2, 0.02, 40, 20 and $4 \mu \mathrm{g} / \mathrm{L}$, respectively. The hydride generation method for As has a detection limit of $0.1 \mu \mathrm{g} / \mathrm{L}$ while the ultrasonic aerosol generator attachment has a detection limit of $1 \mu \mathrm{g} / \mathrm{L}$.

The speciation of As was determined by passing filtered and unacidified leachates/effluents through WATERS Sep-Pak ${ }^{\circledR}$ Plus Acell Plus QMA cartridges (Waters, MA). After the anoxic experiments, aliquots of the liquid samples were immediately filtered through the speciation cartridges to minimize the oxidation of $\mathrm{As}[\mathrm{III}]$ to $\mathrm{As}[\mathrm{V}]$. The QMA cartridges are solid phase extraction cartridges able to immobilize As[V] while allowing As[III] to pass through (Al-Abed et al., 2006; Impellitteri, 2004). Liquid samples passing through the QMA cartridges were collected and analyzed in terms of As[III]. As[V] was then calculated from the total As and As[III] concentrations of the leachate/effluent.

\subsection{Geochemical modeling and mass balance calculations}

PHREEQC (Parkhurst and Appelo, 1999) was utilized to calculate the saturation indices (SI) of important minerals like sulfates, carbonates, oxyhydroxides and oxides, which could potentially affect the leaching and mobility of As in the columns. Four calcium arsenates $\left(\mathrm{Ca}_{5}\left(\mathrm{AsO}_{4}\right) \mathrm{OH}\right.$, $\mathrm{Ca}_{3}\left(\mathrm{AsO}_{4}\right)_{2} \cdot 3 \mathrm{H}_{2} \mathrm{O}, \mathrm{Ca}_{4}(\mathrm{OH})_{2}\left(\mathrm{AsO}_{4}\right)_{2} \cdot 2 \mathrm{H}_{2} \mathrm{O}$ and $\left.\mathrm{CaHAsO}_{4} \cdot 4 \mathrm{H}_{2} \mathrm{O}\right)$ were also included in the model using thermodynamic data and chemical reactions reported by Bothe and Brown (1999) and Zhu et al. (2006). In addition, PHREEQC was utilized to simulate an ideal system consisting only of pyrite and calcite. In this simulation, the amounts of calcite and pyrite were set to 10 and 0.1 moles, respectively, and in equilibrium with pure water $(\mathrm{pH}=7)$. These values were selected because the rock sample contains more calcite than pyrite. The concentrations of dissolved $\mathrm{O}_{2}$ and $\mathrm{CO}_{2}$ were also adjusted from $1 \mathrm{mg} / \mathrm{L}$ to zero. Moreover, an $\mathrm{Eh}-\mathrm{pH}$ diagram of As 
speciation was constructed using the Geochemist's Workbench ${ }^{\circledR}$ (Bethke, 1992) based on the actual effluent chemistry.

Mass balances of As, $\mathrm{Ca}^{2+}$ and $\mathrm{SO}_{4}{ }^{2-}$ were calculated to relate the changes in the effluent chemistry to the dissolution or precipitation of minerals in cases 1-, 2- and 3-anoxic for the first 59, 29 and 15 weeks, respectively. These intervals were selected because around this time, 14 PVs of effluents had been collected in each case. The calculations were done with several assumptions. First, calcite, pyrite and $\mathrm{Ca}-/ \mathrm{Fe}$-sulfates are the primary sources of $\mathrm{Ca}^{2+}$ and $\mathrm{SO}_{4}{ }^{2-}$ in the effluent, and the release of As from the rock was predominantly due to the dissolution of these soluble phases and pyrite oxidation. Second, $\mathrm{Ca}^{2+}$ and $\mathrm{SO}_{4}{ }^{2-}$ concentrations in the effluents during the first 2 PVs (case 1 -anoxic: 1 - 11 weeks; case 2-anoxic: $1-6$ weeks; case 3 -anoxic: 1 -3 weeks) were attributed to the dissolution of soluble $\mathrm{Ca} / \mathrm{Fe}$ sulfates and calcite as well as pyrite oxidation. Third, $\mathrm{Ca}^{2+}$ and $\mathrm{SO}_{4}{ }^{2-}$ concentrations in the effluent after PV 2 were attributed only to calcite dissolution and pyrite oxidation, respectively. Fourth, As due to pyrite oxidation was estimated from the average As concentration in the effluent after apparent equilibrium, which is after ca. week 50 in case 1-anoxic, week 40 in case 2-anoxic and week 20 in case 3anoxic. For the mass balance calculation of As during the spike tests, the average As concentration calculated after apparent equilibrium was assumed as the amount of As released from the rock. Differences between the total As measured and the average As concentration were considered as the contribution of the spike test. All these assumptions were based on the chemical composition, initial column conditions and breakthrough curves that would be discussed below as well as the previous results of the authors (Tabelin et al., 2012a, b). 


\section{RESULTS}

\subsection{Speciation of arsenic in batch experiments under anoxic conditions}

The mobilization and speciation of As under anoxic conditions at different solid-liquid ratios and mixing time are illustrated in Figure 1. At a higher solid-liquid ratio of 1:5, the leaching of As increased with time and did not reach apparent equilibrium even after 24 hours. The concentration of As was $18 \mu \mathrm{g} / \mathrm{L}$ after 30 minutes and increased to $35 \mu \mathrm{g} / \mathrm{L}$ in 24 hours. For the speciation of As at this solid-liquid ratio, As[V] was the dominant species throughout the experiment. As[III] species was only detected after 6 hours, reaching a concentration of $1 \mu \mathrm{g} / \mathrm{L}$ after 24 hours, which was ca. $2.8 \%$ of the total As released from the rock.

At a lower solid-liquid ratio of 1:10, the leaching trend of As also increased with time and did not reach apparent equilibrium after 24 hours similar to those observed at the 1:5 solid-liquid ratio. After 30 minutes, the amount of As in the leachate was only $7 \mu \mathrm{g} / \mathrm{L}$. This amount continuously increased with time reaching a maximum concentration of $20 \mu \mathrm{g} / \mathrm{L}$ after 24 hours. The amount of As leached from the rock almost corresponded to half of those measured at 1:5. For the speciation of As at this solid-liquid ratio, As[V] was the predominant species in the leachate throughout the experiment. The concentration of As[III] also became detectable after 6 hours similar to those observed at a higher solid-liquid ratio, reaching a maximum concentration of $1.4 \mu \mathrm{g} / \mathrm{L}$, which was equal to $6.8 \%$ of the total As leached from the rock.

The $\mathrm{pH}$ and Eh values of the leachates were also affected by both the mixing time and solidliquid ratio as shown in Figures 1(c) and (d). Slightly higher $\mathrm{pH}$ values were measured at 1:10 $(9.74-10.1)$ than at $1: 5(9.78-9.89)$. In addition, the $\mathrm{pH}$ had gradually decreasing trends with increasing mixing time at both solid-liquid ratios. The Eh decreased dramatically after 2 hours 
followed by a gradual increase, but the system remained under oxidizing condition throughout the experiment.

\subsection{Effect of infiltration rate on $\mathrm{pH}$, Eh and the leaching curves of As, $\mathrm{Ca}^{2+}, \mathrm{SO}_{4}{ }^{2-}$ and $\mathrm{Fe}$ under}

\section{laboratory column conditions}

The first effluent sample in case 1 -anoxic was collected on the $4^{\text {th }}$ week, case 2 -anoxic on the $2^{\text {nd }}$ week and case 3-anoxic on the $1^{\text {st }}$ week, which shows that variations of the infiltration rate directly influenced the water residence time in the columns. To put it in another perspective, collecting 14 PVs of effluent took ca. 59, 29 and 15 weeks in cases 1-, 2- and 3-anoxic, respectively (Figure 2(a)). These would roughly translate to average water linear velocities of $1.85,3.72$ and $7.49 \mathrm{~cm} /$ week for cases 1-, 2- and 3-anoxic, respectively, which means that water residence time is inversely proportional to the infiltration rate. However, pore water in this type of column experiments was not uniformly distributed because water was poured intermittently and allowed to infiltrate by gravity. The upper part was unsaturated while the bottom part was close to saturated conditions (Tabelin et al., 2012b). Table 3 shows the water balances in all columns until week 59. Highest percent recovery was obtained in case 3 -anoxic at $97.2 \%$ followed by case 2 -anoxic 7 at $96 \%$ and case 1 -anoxic at $92.5 \%$. In all cases, the differences between the volume of water added and collected were greater than $163.4 \mathrm{~cm}^{3}$ (i.e., PV of the columns), which could be attributed to the cumulative water loss due to evaporation. Figure 2(b) illustrates the evolution of $\mathrm{pH}$ with time at different infiltration rates. In the first 16 weeks of the experiment, the $\mathrm{pH}$ in case 3-anoxic were higher (range: 8.6 - 9.7) than those in cases 1- (range: $7.5-8.4$ ) and 2-anoxic (range: $8.1-8.9$ ). Also, rapid initial increase in $\mathrm{pH}$ was observed in cases 2- and 3-anoxic during the first 8 weeks. After these initial increase, $\mathrm{pH}$ values in these cases slowly decreased and stabilized around week 25 in the range of $7.8-8.6$. In contrast, the 
$\mathrm{pH}$ of case 1-anoxic during the first 10 weeks were lower ( $\mathrm{pH}$ range: $7.5-7.8$ ), then started to slowly increase and stabilized in the same $\mathrm{pH}$ range as those of the other two cases. The $\mathrm{pH}$ of effluents collected after apparent equilibrium was ca. $0.5-2.0 \mathrm{pH}$ units higher than the initial $\mathrm{pH}$ of the degassed deionized water (Table 2). This increase probably occurred as soon as water came in contact with calcite present in the rock. Dissolution of calcite is relatively rapid, which means that the final effluent $\mathrm{pH}$ is most likely reached around the upper part of the columns. The Eh values of all effluent samples were located in the range of $+0.2-+0.4 \mathrm{~V}$, which indicates that the columns were under oxidizing conditions even under anoxic conditions (Figure 2(c)).

The leaching behavior of As with time in the columns under anoxic conditions at varying infiltration rates is illustrated in Figure 2(d). In all three cases, the leaching curves of As were characterized by distinct peaks followed by stabilization. The As concentration peaks in cases 1-, 2- and 3-anoxic were observed at 450, 520 and $570 \mu \mathrm{g} / \mathrm{L}$, respectively. In all cases, concentration peaks of As appeared only during the first 50 weeks of the experiment (around the first $10-15$ PVs). In addition, the width of the As concentration peak taken at $50 \%$ of $\mathrm{C}_{\max }$ (maximum As concentration) in case 1-anoxic was wider (ca. 24 weeks) than those of cases 2- (ca. 16 weeks) and 3-anoxic (ca. 6 weeks). The concentration of As stabilized earlier in case 3-anoxic (ca. week 20) followed by case 2-anoxic (ca. week 40) and then case 1-anoxic (ca. week 50). Statistical analyses (F- and T-tests) showed that As concentrations after stabilization in cases 1- and 2anoxic were similar. However, As concentrations in case 3-anoxic were statistically different from those measured in the other two cases. (Note: Details of the statistical analysis are given in supplementary tables). These statistical results suggest that the As concentration range after stabilization was lower in case 3 -anoxic $(20-50 \mu \mathrm{g} / \mathrm{L})$ than those in case $1-(47-65 \mu \mathrm{g} / \mathrm{L})$ and 2-anoxic $(39-67 \mu \mathrm{g} / \mathrm{L})$. The total mass of As leached was highest in case 3 -anoxic at $0.87 \mathrm{mg}$, 
followed by case 2 -anoxic at $0.79 \mathrm{mg}$ and least in case 1 -anoxic at $0.47 \mathrm{mg}$. However, these values only accounted for ca. $2.9-5.4 \%$ of the total As content of the rock. In contrast, the total masses of As released during the batch experiments were substantially lower at 0.005 and 0.003 $\mathrm{mg}$ (ca. $0.7-0.8 \%$ of the total As content of the rock) for solid-liquid ratios of 1:5 and 1:10, respectively. The higher amount of As leached during the column experiments could be attributed to longer exposure of the rock to leaching conditions as well as the continuous "renewal" of the leachant.

The EC trends corresponded well with the $\mathrm{Ca}^{2+}$ and $\mathrm{SO}_{4}{ }^{2-}$ concentration curves as illustrated in Figures 2(e), (f) and (g), which indicate that these two ions are the major cation and anion in the effluents. In all cases, the concentrations of $\mathrm{Ca}^{2+}$ and $\mathrm{SO}_{4}{ }^{2-}$ were highest at the start of the experiment, decreased rapidly followed by stabilization. This rapid concentration decrease occurred during the first $2 \mathrm{PVs}$ in all cases (case 1-anoxic: week 11; case 2-anoxic: week 6; case 3-anoxic: week 3), and the concentrations of $\mathrm{Ca}^{2+}$ and $\mathrm{SO}_{4}{ }^{2-}$ stabilized in the range of $1-30$ and $10-100 \mathrm{mg} / \mathrm{L}$, respectively. Increasing the infiltration rate also resulted in more effluents with detectable Fe concentrations (Figure 2(h)). In case 1-anoxic about 14 samples had Fe concentrations greater than $0.001 \mathrm{mg} / \mathrm{L}$ while in case 3 -anoxic this number almost doubled to 20 samples. Also, concentrations of Fe in the effluent of all cases were greater than $0.001 \mathrm{mg} / \mathrm{L}$ before week 25. After this, all effluents had Fe concentrations less than $0.001 \mathrm{mg} / \mathrm{L}$.

Figure 3 illustrates the relationship between $\mathrm{Ca}^{2+}$ and As concentrations in the effluent under anoxic conditions. Strong negative and statistically significant correlations $(\mathrm{p}<0.005)$ were observed between $\mathrm{Ca}^{2+}$ and As in all three cases under anoxic conditions (Figure 3), which indicate that the processes responsible for the high $\mathrm{Ca}^{2+}$ concentrations are related to the lower mobility of As. Tables 4, 5 and 6 summarizes the mass balance calculations of As, $\mathrm{Ca}^{2+}$ and 
$\mathrm{SO}_{4}{ }^{2-}$ in the first $14 \mathrm{PVs}$ of cases 1-, 2- and 3-anoxic, respectively. Normalized using the same PVs, total masses of As leached in cases 2- and 3-anoxic (i.e., with higher infiltration rate) were higher than in case 1-anoxic. In contrast, higher amounts of $\mathrm{Ca}^{2+}$ and $\mathrm{SO}_{4}{ }^{2-}$ were leached from case 1-anoxic and decreased with increasing infiltration rate. From these results, ca. $71-84 \%$ of As released from the rock during the first $14 \mathrm{PVs}$ could be attributed to the dissolution of soluble phases. Similarly, ca. $60-86 \%$ of $\mathrm{Ca}^{2+}$ and ca. $72-89 \%$ of $\mathrm{SO}_{4}{ }^{2-}$ leached from the rock during this period (i.e., PV 0 - 14) were due to the dissolution of these soluble phases. The dissolution of calcite and oxidation of pyrite also seem to decrease with increasing infiltration. However, this effect was not apparent in the dissolution of the soluble phases.

\subsection{Effects of anoxic conditions on $\mathrm{pH}$, Eh and the leaching curves of $\mathrm{As}, \mathrm{Ca}^{2+}, \mathrm{SO}_{4}{ }^{2-}$ and $\mathrm{Fe}$} under laboratory column conditions

Figure 4 compares the results of similar columns experiments at low and high infiltration rates under oxic and anoxic conditions. The oxic results were reported in the previous work of the authors (Tabelin et al., 2012b). Columns used in the oxic experiments were constructed in an identical fashion as those in the anoxic experiments, that is, bulk density, rock bed thickness and infiltration rates were the same. They only differed in the concentrations of atmospheric and dissolved $\mathrm{O}_{2}$ and $\mathrm{CO}_{2}$. Anoxic conditions strongly influenced the $\mathrm{pH}$, Eh and As concentrations of the effluents even though the water residence times were similar (Figures 4 (a), (b) and (c)). The $\mathrm{pH}$ values were higher under anoxic conditions by as much as 1 and $2 \mathrm{pH}$ units in cases 1and 3-anoxic, respectively. The $\mathrm{pH}$ also stabilized at a higher range under anoxic condition (7.8 8.6) than oxic condition $(7.3-8.0)$. On the other hand, the Eh values decreased by ca. $0.05 \mathrm{~V}$ under anoxic condition, but still remained under oxidizing conditions. The amount of As released from the rock dramatically increased under anoxic conditions as illustrated in Figure 4(c). The 
As concentration peaks increased from 32 to $450 \mu \mathrm{g} / \mathrm{L}$ (ca. 13-fold) in case 1 and 300 to 570 $\mu \mathrm{g} / \mathrm{L}$ (ca. 1.9-fold) in case 3. The width of the As concentration peak in case 3-anoxic taken at $50 \%$ of $\mathrm{C}_{\max }$ was similar under oxic and anoxic condition. In contrast, the width of the concentration peak in case 1-anoxic was very pronounced, but was not apparent under oxic conditions (case 1-oxic). This dramatic increase in As concentration under anoxic conditions was only observed during the first 20 PVs (ca. 20 weeks in case 3). After that, As concentration of the effluents under oxic and anoxic conditions were close to each other (case 3). Even though the heights and widths of their respective concentration peaks were different, the leaching curves of As under oxic and anoxic conditions had similar leaching trends, that is, a distinct peak followed by stabilization was observed. Apparent equilibrium in terms of As concentration was also delayed especially at lower infiltration rates under anoxic conditions. Apparent equilibrium was not reached in case 1 -anoxic until ca. week 50 while that under oxic condition was already stable after just 23 weeks. At the highest infiltration rate (case 3), apparent equilibrium was reached at approximately the same time (ca. week 16) under oxic and anoxic conditions.

Anoxic conditions also decreased the concentrations of $\mathrm{Ca}^{2+}$ and $\mathrm{SO}_{4}{ }^{2-}$ in the effluent as shown in Figures 4(d) and (e), which was more pronounced at the lowest infiltration rate. During the first 10 weeks (2 PVs) under anoxic conditions, concentrations of $\mathrm{Ca}^{2+}$ and $\mathrm{SO}_{4}{ }^{2-}$ in both cases 1- and 3-anoxic were lower than those under oxic conditions. In case 3-anoxic, the concentrations of the $\mathrm{Ca}^{2+}$ and $\mathrm{SO}_{4}{ }^{2-}$ decreased by as much as 200 and $1,570 \mathrm{mg} / \mathrm{L}$, respectively. Even after 2 PVs, the concentrations of these two ions in both cases were consistently lower under anoxic than oxic conditions. Concentrations of $\mathrm{Ca}^{2+}$ averaged 84 and $18 \mathrm{mg} / \mathrm{L}$ for cases 1oxic and 3-oxic, respectively. In contrast, these concentrations decreased dramatically under anoxic conditions averaging 10 and $11 \mathrm{mg} / \mathrm{L}$ for cases 1 - and 3-anoxic, respectively. Similarly, 
$\mathrm{SO}_{4}{ }^{2-}$ concentrations of the effluents under ambient conditions averaged 301 and $60 \mathrm{mg} / \mathrm{L}$ for cases 1-oxic and 3-oxic, respectively while those collected under anoxic conditions were significantly lower at 56 and $21 \mathrm{mg} / \mathrm{L}$ for the same cases. These amounted to as much as 10 -fold and 5-fold decrease in the concentrations of $\mathrm{Ca}^{2+}$ and $\mathrm{SO}_{4}{ }^{2-}$, respectively. Regardless of these differences, $\mathrm{Ca}^{2+}$ and $\mathrm{SO}_{4}{ }^{2-}$ had identical "flushing-out" trends under oxic and anoxic conditions, that is, the concentrations were initially high followed by a rapid decrease with time. Anoxic conditions also had a strong effect on the Fe concentration as illustrated in Figure 4(f). In all cases, anoxic conditions resulted in higher concentrations of Fe in the effluent regardless of the infiltration rate. Only 2 effluent samples had Fe concentrations greater than $0.001 \mathrm{mg} / \mathrm{L}$ under oxic condition while 44 samples with detectable Fe concentrations were collected under anoxic conditions.

\subsection{Spike test and distribution of arsenic with depth}

Figure 5(a) shows the results of tracer tests using $\mathrm{Br}^{-}$after apparent equilibrium. The mean time $\left(t_{\text {mean }}\right)$ was calculated using the following equation:

$$
t_{\text {mean }}=\frac{\theta_{\text {ave }} V}{Q_{\text {ave }}} \quad \text { Equation } 1
$$

where, $t_{\text {mean: }}$ average travel time of water (week), $\theta_{\text {ave: }}$ average volumetric water content $\left(\mathrm{cm}^{3} / \mathrm{cm}^{3}\right), V$ : volume of rock bed $\left(\mathrm{cm}^{3}\right)$, and $Q_{a v e}$ : average volumetric flow rate $\left(\mathrm{cm}^{3} /\right.$ week $)$. The average volumetric water content $\left(\theta_{\text {ave }}\right)$ was estimated from the mass of influent added and the mass of effluent collected during the first couple of weeks of the experiments assuming that the loss of water through evaporation was negligible. Similarly, the volumetric flow rate was calculated from the mass of effluent collected during the spike test. In addition, $t=0$ in the figure refers to the time of tracer introduction (week 60). 
The tracer concentration peaks in cases 1 - and 2 -anoxic almost correspond to $t / t_{\text {mean }}=1$, indicating that most of the tracer were transported at the same time as the bulk of the fluid. The features of these curves are typical for a less heterogeneous flow system with small dispersions (Birkholzer and Tsang, 1997). In case 3-anoxic, the curve was fitted to the data points based on the trend observed in the first two cases, that is, the peak was almost twice as that in case 2anoxic when the amount of tracer added was doubled. Higher tracer peaks were observed in cases 2- and 3-anoxic because of the higher amounts of tracer added in these cases. In addition, the tail end of the tracer peaks in cases 1- and 2-anoxic were more pronounced than that in case 3-anoxic, meaning that substantial part of the tracer travelled slower than the bulk fluid in columns with lower infiltration rates. These results suggest that although some of the tracer travel their way through low-permeable zones, the overall water flow in the columns was not facilitated by fast channeling effect (Moreno and Tsang, 1994). These conservative solute behaviors are typical in systems with intermediate degrees of heterogeneity and saturation (Birkholzer and Tsang, 1997; Moreno and Tsang, 1994). The rapid transport of the tracer is similar to those observed in the leaching trends of more conservative ions like $\mathrm{Ca}^{2+}$ and $\mathrm{SO}_{4}{ }^{2-}$. However, the gradual increase and decrease of As concentration with time, which is strikingly different from those of $\mathrm{Ca}^{2+}$ and $\mathrm{SO}_{4}{ }^{2-}$, suggests that chemical reactions have far greater influence on the mobilization of As than water flow characteristics.

Even under anoxic conditions, the altered rock was capable of attenuating additional As loadings including As[III] as illustrated in Figure 5(b) and Table 7. In case 1-anoxic where 0.418 mg of As[III] was introduced, a slight increase in the concentration of As was observed resulting in a small peak between weeks 64 and 75. This concentration peak of As was ca. $80 \mu \mathrm{g} / \mathrm{L}$ which was ca. $20 \mu \mathrm{g} / \mathrm{L}$ higher than the effluent As concentration prior to the spike test. However, this 
small increase only accounted for ca. $1 \%$ of the total As[III] spiked into the column. There was insignificant As concentration increase in case 2-anoxic where As[V] species was added amounting to $0.833 \mathrm{mg}$, but doubling both this amount (case 3-anoxic; $1.67 \mathrm{mg}$ ) and the infiltration rate dramatically increased the concentration of As from ca. 30 to ca. $120 \mu \mathrm{g} / \mathrm{L}$. This As concentration increase started at week 61 and continued until the end of the experiment. Even at this high infiltration rate and As concentration, the rock was able to retain ca. $80 \%$ of the As spiked in case 3-anoxic (Table 7).

Figure 6 shows the distribution of As in the pore water of cases 1,2 and 3 under anoxic conditions. In case 1-anoxic, the maximum As concentration was observed around the middle of the column amounting to $155 \mu \mathrm{g} / \mathrm{L}$ whilst pore water As concentrations at the top (depth: $0-60$ $\mathrm{mm}$ ) and bottom (depth: $120-200 \mathrm{~mm}$ ) were lower. In case 2-anoxic, As concentrations in the pore water was initially $29 \mu \mathrm{g} / \mathrm{L}$, increased with depth until a maximum value of $76 \mu \mathrm{g} / \mathrm{L}$ was reached followed by a decrease in concentration reaching a final value of $54 \mu \mathrm{g} / \mathrm{L}$. This trend of As concentration increase followed by a decrease with depth observed in case 2-anoxic became more pronounced in case 3-anoxic. The As concentration profile with depth in case 1-anoxic was a little different compared to the other cases, which might be due to differences in the properties of As species used in the spike tests. Regardless of these differences, all three cases had similar As concentration trends in the pore water with depth, that is, both top and bottom regions had lower As concentration relative to the middle of the column.

\subsection{Temporal and spatial speciation of arsenic in the columns}

An Eh-pH diagram illustrating the speciation of As is shown in Figure 7. This diagram was constructed using the maximum concentrations of dissolved species measured in the effluents (activity of $\mathrm{As}=10^{-6}$; activity of $\mathrm{SO}_{4}{ }^{2-}=10^{-3}$ ). The two boxes in the figure mark the range of $\mathrm{pH}$ 
and Eh values measured during the anoxic column experiments. Thermodynamically, As[V] is the predominant As species under the $\mathrm{pH}$ and Eh conditions of the experiments, but actual measurements of $\mathrm{As}[\mathrm{III}]$ and As[V] illustrate a more complex relationship as shown in Figure 8. During the first couple of weeks of the experiment, As in the effluent was predominantly composed of As[V] at around $97-99 \%$ of the total As concentration. Around the middle stages of the experiment (weeks $20-50$ ), As[III] replaced As[V] as the dominant As species of the effluent amounting to as much as $81 \%$ of the total As concentration. Towards the last couple of weeks of the experiment, the major As species reverted back to As[V], but was slightly lower (58 - 99\%) compared to those measured during the initial stages of the experiment. This trend of As speciation wherein As[V] predominated at the start and end while As[III] was dominant in the middle part of the experiment was observed in both cases 2 -anoxic and 3 -anoxic. These differences in As[III] and As[V] concentrations are all statistically significant based on the results of F- and T-tests (Note: Details of the statistical analysis are given in supplementary tables). Arsenic speciation analysis could not be done in case 1-anoxic due to the limited amount of effluents collected. The spatial distribution of As species in the pore water in case 2-anoxic is shown in Figure 9. As[V] was the predominant species at any depth, but substantial concentration of As[III] was measured at the top pore water of the column.

\subsection{Post experimental determination of mineral phases using SEM-EDS}

Figures $10 \mathrm{~A}$ and B illustrate the presence of Fe-sulfides and Fe-oxyhydroxides in the bottom section of case 2-anoxic. The marked portion of the elemental maps of Fe and $\mathrm{S}$ in Figure 10A coincided well with each other indicating that this mineral is a finely grained Fe-sulfide, most likely pyrite, which persisted even after 90 weeks of column experiments. Similarly, elemental maps of Fe and $\mathrm{O}$ coincided well with each other in the marked portion of Figure 10B suggesting 
that Fe-oxyhydroxides/oxides are also present in the columns. In these figures, the marked portions of the elemental maps clearly showed strong Fe, S and $\mathrm{O}$ signals compared to those of the background elements like $\mathrm{Si}, \mathrm{Al}$ and $\mathrm{Mg}$ found in the silicate-aluminate mineral matrix of the rock.

\section{DISCUSSION}

\subsection{Water residence time, mineral dissolution and $\mathrm{pH}$ variability}

Under anoxic conditions, the effects of water residence on mineral dissolution and $\mathrm{pH}$ variability became more apparent. Shorter water residence time resulted in the faster dissolution and flushing-out of soluble phases as well as the higher $\mathrm{pH}$ values of the effluents. In addition, mass balance calculations indicated that the oxidation of pyrite and dissolution of calcite increased at longer water residence time, which was consistent with the lower $\mathrm{pH}$ values observed at lower infiltration rates (Figure 2(a)). Relatively high concentrations of $\mathrm{Ca}^{2+}$ and $\mathrm{SO}_{4}{ }^{2-}$ were also observed at the start of the experiment and their flushing-out trends could be attributed to the presence of soluble phases like Ca-sulfates (e.g., gypsum) and Fe-sulfates in the rock, which are most likely secondary mineral products of pyrite oxidation prior to sampling (Figures 2 and 10B) (De Donato et al., 1993; Tabelin et al., 2012a; Todd et al., 2003). Substantial $\mathrm{SO}_{4}{ }^{2-}$ concentration decrease in all cases under anoxic conditions suggests that pyrite oxidation is minimized. Precipitation of calcium arsenates and arsenites, which are important sinks of As at circumneutral - alkaline $\mathrm{pH}$, was not thermodynamically possible even at relatively high $\mathrm{Ca}^{2+}$ concentrations (>300 mg/L) (Figure 11). In contrast, precipitation of Fe-oxyhydroxides/oxides is thermodynamically favorable even under anoxic conditions (Figure 11). However, depleted $\mathrm{O}_{2}$ supply reduced the magnitude of this process resulting in the higher Fe concentrations in the 
effluent under anoxic conditions (Figures 4(f)) (Tabelin et al., 2012b). However, aside from the oxyhydroxides/oxides of $\mathrm{Fe}$, those of $\mathrm{Al}$ would also thermodynamically precipitate based on the calculated $S I$ values (Figure 11), which could further enhance the ability of the rock to mitigate the migration of As.

The large $\mathrm{pH}$ variations with time especially during the first 15 weeks of the experiment could be attributed to the combined effects of water residence time and anoxic conditions on the dissolution of calcite and other soluble phases, pyrite oxidation and the precipitation of Feoxyhydroxides/oxides. Around this time interval (ca. 1 - 10 weeks) the effect was more pronounced probably because of the presence of soluble phases that released Fe ions that could affect pyrite oxidation and Fe-hydroxide/oxyhydroxide precipitation. At higher infiltration rates (i.e., shorter water residence time) the flushing-out of dissolved Fe and rapid renewal of pore water decreased the concentration of $\mathrm{Fe}$ in the effluent that minimized the extent of $\mathrm{Fe}$ oxyhydroxide/oxide precipitation. This could happen at shorter water residence time because dissolved Fe in the effluent is not saturated enough for precipitation to occur, which would result in higher $\mathrm{pH}$ values of the effluent. In addition, the $\mathrm{pH}$ of the effluent is strongly dependent on $\mathrm{O}_{2}$ and $\mathrm{CO}_{2}$ that are important in the oxidation of pyrite, precipitation of $\mathrm{Fe}-$ oxyhydroxides/oxides and dissolution of calcite (Appelo and Postma, 2005; Moses and Herman, 1991; Moses et al., 1987). Both pyrite oxidation and Fe-oxyhydroxides/oxides precipitation increase the concentration of $\mathrm{H}^{+}$ions in solution, which tend to decrease the $\mathrm{pH}$ of the system as illustrated by the following equations:

$$
\begin{array}{lll}
\mathrm{FeS}_{2(\mathrm{~s})}+15 / 4 \mathrm{O}_{2(\mathrm{~g})}+5 / 2 \mathrm{H}_{2} \mathrm{O} & \rightarrow \mathrm{FeOOH}_{(\mathrm{s})}+4 \mathrm{H}^{+}+2 \mathrm{SO}_{4}{ }^{2-} & \text { Equation 2 } \\
2 \mathrm{FeS}_{2(\mathrm{~s})}+15 / 2 \mathrm{O}_{2(\mathrm{~g})}+4 \mathrm{H}_{2} \mathrm{O} & \rightarrow \mathrm{Fe}_{2} \mathrm{O}_{3(\mathrm{~s})}+8 \mathrm{H}^{+}+4 \mathrm{SO}_{4}{ }^{2-} & \text { Equation 3 } \\
\mathrm{FeS}_{2(\mathrm{~s})}+15 / 4 \mathrm{O}_{2(\mathrm{~g})}+7 / 2 \mathrm{H}_{2} \mathrm{O} & \rightarrow \mathrm{Fe}(\mathrm{OH})_{3(\mathrm{~s})}+4 \mathrm{H}^{+}+2 \mathrm{SO}_{4}{ }^{2-} & \text { Equation 4 }
\end{array}
$$




$$
\begin{array}{ll}
\mathrm{Fe}^{2+}+1 / 4 \mathrm{O}_{2(\text { aq })}+21 / 2 \mathrm{H}_{2} \mathrm{O} \rightarrow \mathrm{Fe}(\mathrm{OH})_{3(\mathrm{~s})}+2 \mathrm{H}^{+} & \text {Equation 5 } \\
\mathrm{Fe}^{2+}+2 \mathrm{H}_{2} \mathrm{O} \rightarrow \mathrm{Fe}(\mathrm{OH})_{2(\mathrm{~s})}+2 \mathrm{H}^{+} & \text {Equation 6 }
\end{array}
$$

Under anoxic conditions, the extent of these two processes is thermodynamically reduced resulting in higher $\mathrm{pH}$ values of the effluent. In addition, depletion of dissolved $\mathrm{CO}_{2}$ in the system would make the system "closed" with respect to $\mathrm{CO}_{2}$ that would further increase the $\mathrm{pH}$ (Appelo and Postma, 2005). These combined effects of water residence time and dissolved gases (i.e., $\mathrm{O}_{2}$ and $\mathrm{CO}_{2}$ ) on the $\mathrm{pH}$ of the effluent are supported by the observed lower concentrations of $\mathrm{Ca}^{2+}$ and $\mathrm{SO}_{4}{ }^{2-}$ as well as the higher concentration of $\mathrm{Fe}$ in the effluents under anoxic conditions (Figure 4).

Based on these results, the evolution of $\mathrm{pH}$ under anoxic condition could be divided into 2 stages: stage 1 (weeks $1-25$ ) where large $\mathrm{pH}$ fluctuations were observed, and stage 2 (weeks 26 -59) where the $\mathrm{pH}$ stabilized. In the short term (stage 1), the $\mathrm{pH}$ is most likely controlled by the dissolution of calcite and other soluble-mineral phases like Fe/Ca sulfates, pyrite oxidation and the precipitation of Fe-oxyhydroxides/oxides. After the dissolution of most of these soluble phases, the combined effects of pyrite oxidation, calcite dissolution and $\mathrm{Fe}-$ oxyhydroxides/oxides precipitation would determine the $\mathrm{pH}$ of the effluent. However, the effects of calcite dissolution on the overall $\mathrm{pH}$ far outweighed those of pyrite oxidation and $\mathrm{Fe}$ oxyhydroxides/oxides precipitation, which is evident in the observed alkaline $\mathrm{pH}$ of the effluents throughout the experiment. These deductions are supported by our geochemical modeling results where calcite and pyrite were equilibrated in pure water at depleted $\mathrm{O}_{2}$ and $\mathrm{CO}_{2}$ concentrations (Table 8). Furthermore, SEM-EDS maps of the rock after the experiments confirmed the presence of Fe-sulfide and oxyhydroxides/oxides minerals that are key components of the $\mathrm{pH}$ evolution processes discussed above (Figure 10A and B). Based on these results and those 
presented in the previous paper of the authors (Tabelin et al., 2011b), the processes controlling the $\mathrm{pH}$ of the altered rock are similar under both oxic and anoxic conditions, and are due to the following: dissolution, pyrite oxidation and precipitation reactions.

\subsection{Arsenic mobilization under anoxic conditions}

Mass balance calculations showed that the amount of As released from the rock was lower at longer water residence times, although the opposite was observed for the amounts of leached $\mathrm{Ca}^{2+}$ and $\mathrm{SO}_{4}{ }^{2-}$. As discussed above, longer water residence time enhanced pyrite oxidation, calcite dissolution and Fe-oxyhydroxide/oxide precipitation, which resulted in lower $\mathrm{pH}$ values especially during the initial stages of the experiment when the contribution of soluble phases was very high. These results suggest that the water residence time affects As mobilization under anoxic conditions via two interrelated processes. First, rapid dissolution and transport of As from soluble phases at shorter water residence time minimize the immobilization of As through adsorption and/or co-precipitation reactions. Second, water residence time affects the $\mathrm{pH}$ of the rock-water system through its interactions with pyrite and calcite, which are the primary $\mathrm{pH}$ controlling minerals of altered rocks (Tabelin et al., 2012a).

Similar As leaching trends under oxic and anoxic conditions indicate that the mechanisms of As release under both conditions are probably similar, and could include one or more of the following: dissolution of soluble phases, pyrite oxidation and adsorption/desorption reactions (Case 3 in Figure 4). However, the substantial increase in As concentrations under anoxic conditions demonstrated that immobilization processes most likely those pertaining to the adsorption of As onto Fe oxyhydroxides/oxides precipitates had been greatly reduced. In the first couple of weeks of the experiment, the amount of As in the effluent was low because of the high $\mathrm{Ca}^{2+}$ concentration of the effluent that enhanced adsorption through the formation of more 
positively-charged mineral surfaces (Ghosh and Teoh, 1985; Meng et al., 2000; Stachowicz et al., 2008; Wilkie and Herring, 1996). However, this positive effect of $\mathrm{Ca}^{2+}$ on As adsorption was only temporary, and as soon as the concentration of $\mathrm{Ca}^{2+}$ decreased below ca. $50 \mathrm{mg} / \mathrm{L}$, As leaching was enhanced significantly. Dissolution of soluble Fe-bearing phases and pyrite oxidation also released considerable amounts of Fe ions into solution in addition to As. Precipitation of dissolved Fe could effectively lower the concentration of As via co-precipitation and adsorption reactions (Cornelis et al., 2008; Dousova et al., 2003; Dzombak and Morel, 1990; Ghosh and Teoh, 1985; Wang and Mulligan, 2006). However, depletion of $\mathrm{O}_{2}$ under anoxic conditions reduced the extent of $\mathrm{Fe}$ oxyhydroxides/oxides precipitation resulting in high $\mathrm{Fe}$ and As concentrations of the effluent (Figure 4). After most of the soluble Fe and As-bearing phases were dissolved, the release of As was probably due to the continued oxidation of pyrite because majority of As in this rock is associated with sulfide minerals like pyrite. However, a portion of these released As is also immobilized via adsorption onto Fe-oxyhydroxides/oxides precipitates that are formed as a consequence of pyrite oxidation (Equations $2-4$ ). These deductions are supported by our geochemical modeling (Table 8; Figure 11), which showed that the measured $\mathrm{pH}$ and concentrations of $\mathrm{Ca}^{2+}$ and $\mathrm{SO}_{4}{ }^{2-}$ after week 25 agreed well with the calcite-pyrite system used in the model. In addition, evidence of Fe-sulfides and Fe-oxyhydroxides/oxides was found in the altered rock after the column experiments using SEM-EDS (Figures 10A and B).

Under anoxic conditions, the absence/depletion of $\mathrm{O}_{2}$ minimized pyrite oxidation, but was insufficient in lowering the concentration of As in the effluent below the drinking water standard of Japan $(10 \mu \mathrm{g} / \mathrm{L})$. Thermodynamics dictates that pyrite oxidation becomes negligible in the absence of $\mathrm{O}_{2}$ as illustrated by the very low concentration of $\mathrm{SO}_{4}{ }^{2-}$ in our geochemical modeling calculations (Table 8). However, the actual $\mathrm{SO}_{4}{ }^{2-}$ concentrations measured in the effluents were 
more than 4 orders of magnitude higher than the predicted values, and were closer to the simulation results with trace amounts of $\mathrm{O}_{2}$ and $\mathrm{CO}_{2}$ (Table 8). Actual measurements of DO concentrations of the deionized water showed that trace amounts still existed $(0.1-0.3 \mathrm{mg} / \mathrm{L})$. This indicates that pyrite oxidation occurred in the columns because of these trace amounts of DO in the deionized water albeit at a kinetically slower rate. It was difficult to completely eliminate DO in the experiments, but DO was substantially lowered from ca. $10 \mathrm{mg} / \mathrm{L}$ (under ambient condition) to concentrations that approximated anoxic conditions.

There was also a spatial distribution of As with depth under anoxic conditions similar to those reported in our previous work under oxic conditions (Tabelin et al., 2012b), which means that the columns are also divided into 2 distinct regions: a leaching region and an adsorption region. Mobilization of As was dominant in the upper half of the columns (leaching region) while the remaining half favored immobilization processes like adsorption (adsorption region) (Figure 6). However, under anoxic conditions, effectiveness of this adsorption layer was greatly diminished because of reduced Fe oxyhydroxide/oxide precipitation (Figure 2; Equations 5 - 6). In general, the results of this study and those reported in the previous paper of the authors (Tabelin et al., 2012b) show that the temporal and spatial release mechanisms of As from altered rock at slightly alkaline $\mathrm{pH}$ conditions are the same under both oxic and anoxic conditions.

\subsection{Arsenic speciation under anoxic conditions}

The speciation of As in the columns under anoxic conditions was more complex than those predicted by the Eh-pH diagram (Figures 7 and 8). As[V] concentrations exceeded those of As[III] at the beginning and the end of the column experiments ( 0 - 25 weeks and again after about 50 weeks), which are consistent with the prediction of the Eh-pH diagram based on the measured $\mathrm{pH}$ and Eh of the effluents. However, As[III] predominated in the effluents collected around the middle stages of 
the experiment, indicating that in addition to $\mathrm{pH}$ and $\mathrm{Eh}$, other factors and/or processes strongly influenced the speciation of As released from the rock.

The release of As[III] species from the altered rock was somewhat delayed under anoxic conditions. In the batch experiments, As[III] only became substantial after 6 hours. This was delayed by more than 5 hours in comparison to those observed under oxic conditions (Tabelin $e t$ al., 2012b). Apparent equilibrium in terms of the total As concentration was not achieved under anoxic conditions even after 24 hours in the batch experiments. In contrast, apparent equilibrium was observed under oxic conditions only after ca. 6 hours (Tabelin et al., 2012b). This delay in the apparent equilibrium of As species was also observed in the column experiments (Figure 8). One of the processes that probably had strong influence on the speciation of As in the columns is the precipitation of Fe-oxyhydroxides/oxides and the subsequent adsorption of As species (Raven et al., 1998). In contrast to the oxic results, concentration peaks of As[III] were not observed during the first 20 weeks of the experiment under anoxic conditions (Figure 8; Figure 8 in Tabelin et al. (2012b)). Significant concentrations of As[III] were not observed during these early stages of the anoxic experiment probably because of its preferential adsorption onto Fe oxyhydroxides/oxides at higher $\mathrm{pH}$. As the $\mathrm{pH}$ decreases, adsorbed As[III] are replaced by As[V] resulting in its release into effluent after the total As concentration peak (Figure 8). The $\mathrm{pH}$ dependent adsorption of As species occurs because of electrostatic differences between As oxyanions and the surface of Fe oxyhydroxides (Raven et al., 1998). As[V] is generally present as a negatively charged oxyanion $\left(\mathrm{HAsO}_{4}{ }^{2-}\right)$ while $\mathrm{As}[\mathrm{III}]$ is in the uncharged form $\left(\mathrm{H}_{3} \mathrm{AsO}_{3}\right)$. At higher $\mathrm{pH}(\mathrm{ca} .8-9.5)$, the surface charge of Fe oxyhydroxides becomes more negative, which results in the preferential adsorption of the uncharged As[III] oxyanion. However, at lower $\mathrm{pH}$ the surface charge of these oxyhydroxides becomes more positive resulting in the desorption of the uncharged As[III] oxyanion and the preferential adsorption of the negatively charged As[V] 
oxyanion. As the columns approached apparent equilibrium $(\mathrm{pH} \sim 8.5), \mathrm{As}[\mathrm{V}]$ became the dominant As species of the effluent consistent with the geochemical modeling calculations and the results of the batch experiments. The importance of electrostatic repulsion and attraction on the speciation of As especially at low total As concentration is supported by other researchers (Raven et al., 1998; Stachowicz et al., 2008).

With depth, As[V] was the predominant As species in the pore water, but significant As[III] was observed at the upper part (top $20 \mathrm{~mm}$ ) of the column (Figure 9). The decrease of As[III] in the pore water with depth may occur as a consequence of oxidation and adsorption reactions. Oxidation of As[III] to As[V] probably happened because of the interactions of As[III] with organic matter and/or manganese oxides found in the altered rock at trace amounts (Chiu and Hering, 2000; Redman et al., 2002; Tabelin et al., 2012b). In addition, oxidation of As[III] is possible due to the presence of $\mathrm{As}[\mathrm{V}]$ at low total As concentration characteristic of this experiment (Jang and Dempsey, 2007). Oxidation of As[III] to As[V] enhances As immobilization because of the higher adsorption affinity of As[V] especially at lower $\mathrm{pH}$ conditions $(\mathrm{pH}<9)$.

\section{CONCLUSIONS}

Large volume of hydrothermally altered rocks excavated during road-tunnel projects are potential sources of soil and groundwater contamination because of their elevated toxic elements content. Therefore, it is of critical importance to understand the leaching behavior and release mechanisms of the toxic elements from these sources that will aid in the development of appropriate mitigation approaches for these hazardous wastes. In this research, the mobilization

and speciation of As from a calcite-pyrite-bearing altered excavated rock were investigated under anoxic conditions. Anoxic conditions enhanced the release of As from the altered rock because 
of the associated $\mathrm{pH}$ increase and reduction of $\mathrm{Fe}$ oxyhydroxides/oxides precipitation. The amount of As released from the rock was further increased at shorter water residence times (i.e., higher infiltration rates) due to the rapid transport of dissolved As that minimized its immobilization through co-precipitation and/or adsorption reactions. The effects of these factors were more pronounced especially during the first couple of weeks of the experiment when the dissolution of soluble phases was more significant. Both the temporal and spatial mechanisms of As release from the altered rock under anoxic conditions were similar to those observed under oxic conditions. The release of As[III] was somewhat delayed under anoxic conditions, but could still be partly attributed to the $\mathrm{pH}$ dependent adsorption of As species onto $\mathrm{Fe}$ oxyhydroxides/oxides precipitates. Moreover, less Fe oxyhydroxides/oxides precipitates due to anoxic conditions decreased the natural attenuation capacity of the altered rock that resulted in significant As concentration increase especially after the introduction of additional As loadings.

\section{Acknowledgment}

The authors wish to thank Dr. Jacqueline Satur for her assistance during the SEM-EDS analysis of the samples and the reviewers for their valuable inputs to this paper.

\section{References}

Acharyya, S.K., Lahiri, S., Raymahashay, B.C., Bhowmik, A., 2000. Arsenic toxicity of groundwater in parts of the Bengal basin in India and Bangladesh: The role of Quarternary stratigraphy and Holecene sea level-fluctuation. Environmental Geology 39(10), 1127-1137.

Aiuppa, A., Avino, R., Brusca, L., Caliro, S., Chiodini, G., D’Alessadro, W., Favara, R., Federico, C., Ginevra, W., Inguaggiato, S., Longo, M., Pecoraino, G., Valenza, M., 2006. Mineral control of arsenic content in thermal waters from volcano-hosted hydrothermal systems: Insights from the island of Ischia and Phlegrean Fields. Chemical Geology 229, 313 - 330.

Akai, J., Izumi, K., Fukuhara, H., Masuda, H., Nakano, S., Yoshimura, T., Ohfuji, H., Anwar, H.M., Akai, K., 2004. Mineralogical and geomicrobial investigations on groundwater arsenic enrichment in Bangladesh. Applied Geochemistry 19, 215-230. 
Al-Abed, S.R., Hageman, P.L., Jegadeesan, G., Madhavan, N., Allen, D., 2006. Comparative evaluation of short-term leach tests for heavy metal release from mineral processing waste. Science of the Total Environment 364, 14-23.

Allen, K.D., Hahn, G.A., 1994. Geology of Sunbeam and Grouse Creek gold-silver deposits, Yankee Fork mining district, Eocene Challis volcanic field, Idaho: A volcanic dome and volcaniclastic-hosted epithermal system. Economic Geology 89, 1964-1982.

Appelo, C.A.J, Postma, D., 2005. Geochemistry, groundwater and pollution, $2^{\text {nd }}$ ed. A.A. Balkema Publishers, London.

American Society for Testing and Materials, 1989. Standard test method for leaching solid waste in column apparatus (Method D 4874-89). American Society of Testing and Materials, Philadelphia, PA.

Bethke, C.M., 1992. The Geochemist's Workbench - A User's guide to Rxn, Act2, Tact, React and Gtplot. University of Illinois, Urbana, Illinois.

Birkholzer, J., Tsang, C.F., 1997. Solute channeling in unsaturated heterogenous porous media. Water Resources Research 33(10), 2221-2238.

Bothe Jr., J.V., Brown, P.W., 1999. The stabilities of calcium arsenates at $23 \pm 1{ }^{0} \mathrm{C}$. Journal of Hazardous Materials 69, 197-207.

Cebrian, M.E., Albores, A., Aquilar, M., Blakely, E., 1983. Chronic arsenic poisoning in the North of Mexico. Hum. Toxicol. 2, 121-133.

Chakraborty, A.K., Saha, K.C., 1987. Arsenical dermatosis from tubewell water in West Bengal. Indian J. Med. Res. 85, 326-334.

Chen, C.J., Chuang, Y.C., Lin, T.M., Wu, H.Y., 1985. Malignant neoplasms among residents of a blackfoot disease-endemic area in Taiwan: High-arsenic artesian well water and cancers. Cancer Res. 45(11), 5895-5899.

Chen, C.J., Chen, C.W., Wu, M.M., Kuo, T.L., 1992. Cancer potential in liver, lung, bladder and kidney due to ingested inorganic arsenic in drinking water. Br. J. Cancer 66(5), 888-892.

Chiu, V.Q., Hering, J.G., 2000. Arsenic adsorption and oxidation at manganite surfaces. 1. Method for simultaneous determination of adsorbed and dissolved arsenic species. Environmental Science and Technology 34, 2029-2034.

Cornelis, G., Anette-Johnson, C., Van Gerven, T., Vandecasteele, C., 2008. Leaching mechanisms of oxyanionic metalloid and metal species in alkaline solid wastes: A review. Applied Geochemistry 23, 955-976. 
Das, D., Samanta, S., Mandal, B.K., Chowdhury, T.R., Chanda, C.R., Chowdry, P.P., Basu, G.K., Chakraborti, D., 1996. Arsenic in groundwater in six districts of West Bengal, India. Environmental Geochemistry and Health 18, 5-15.

Davis, A., Ashenberg, D., 1989. The aqueous geochemistry of the Berkeley pit, Butte, Montana, U.S.A. Applied Geochemistry 4, 23-36.

Davis, A., Bellehumeur, T., Hunter, P., Hanna, B., Fennemore, G.G., Moomaw, C., Schoen, S., 2006. The nexus between groundwater modeling, pit lake chemogenesis and ecological risk from arsenic in the Getchell main pit, Nevada, USA. Chemical Geology 228, 175-196.

De Donato, P., Mustin, C., Benoit, R., Erre, R., 1993. Spatial distribution of iron and sulphur species on the surface of pyrite. Applied Surface Science 68, 81 - 93.

Dousova, B., Machovic, V., Kolousek, D., Kovanda, F., Dornicak, V., 2003. Sorption of As (V) species from aqueous solution. Water, Air, \& Soil Pollution 149, 251-267.

Dowling, C.B., Poreda, R.J., Basu, A.R., Peters, S.L., Aggarwal, P.K., 2002. Geochemical study of arsenic release mechanisms in the Bengal Basin groundwater. Water Resources Research 38(9), 1173.

Dzombak, D.A., Morel, F.M.M., 1990. Surface Complexation Modeling: Hydrous Ferric Oxide, John Wiley and Sons, New York.

Eary, L.E., 1999. Geochemical and equilibrium trends in mine pit lakes. Applied Geochemistry 14, 963-987.

Fleet, M.E., MacLean, P.J., Barbier, J., 1989. Oscillatory-zoned As-bearing pyrite from stratabound and stratiform gold deposits: An indicator of ore fluid evolution. Economic Geology Monograph 6, $356-362$.

Ghosh, M.M., Teoh, R.S., 1985. Adsorption of arsenic on hydrous aluminum oxide. In: Proceedings of the Seventh Mid-Atlantic Industrial Waste Conference, Lancaster, PA, 139-155.

Halbach, P., Pracejus, B., Marten, A., 1993. Geology and mineralogy of massive sulfide ores from Okinawa trough, Japan. Economic Geology 88, 2210-2225.

Horton, T.W., Becker, J.A., Craw, D., Koons, P.O., Page Chamberlain, C., 2001. Hydrothermal arsenic enrichment in an active mountain belt: Southern Alps, New Zealand. Chemical Geology $177,323-339$.

Huston, D.L., Sie, S.H., Sauter, G.F., Cook, D.R., Both, R.A., 1995. Trace elements in sulfide minerals from eastern Australian volcanic-hosted massive sulfide deposits: Part 1. Proton microprobe analyses of pyrite, chalcopyrite and sphalerite, and Part 2. Selenium levels in pyrite: Comparison with $\delta^{34} \mathrm{~S}$ values and implications for the source of sulfur in volcanogenic hydrothermal systems. Economic Geology 90, 1167-1196. 
Igarashi, T., Imagawa, H., Uchiyama, H., Asakura, K., 2008. Leaching behavior of arsenic from various rocks by controlling geochemical conditions. Minerals Engineering 21, 191-199.

Impellitteri, C.A., 2004. Effects of $\mathrm{pH}$ and competing anions on the speciation of arsenic in fixed ionic strength solutions by solid phase extraction cartridges. Water Research 38, 1207-1214.

Jang, J.H., Dempsey, B.A., 2008. Coadsorption of arsenic(III) and arsenic(V) onto hydrous ferric oxide: Effects of abiotic oxidation of arsenic(III), extraction efficiency, and model accuracy. Environmental Science and Technology 42, 2893-2898.

Levy, D.B., Custis, K.H., Casey, W.H., Rock, P.A., 1997. The aqueous geochemistry of the abandoned Spenceville copper pit, Nevada County, California. Journal of Environmental Quality 26, 233-243.

Meng, X., Bang, S., Korfiatis, G.P., 2000. Effects of silicate, sulfate, and carbonate on arsenic removal by ferric chloride. Water Research 34, 1255-1261.

Moreno, L., Tsang, C.F., 1994. Flow channeling in strongly heterogeneous porous media: A numerical study. Water Resources Research 30, 1421-1430.

Moses, C.O., Herman, J.S., 1991. Pyrite oxidation at circumneutral pH. Geochimica Cosmochimica Acta 55, 471-482.

Moses, C.O., Nordstrom, D.K., Herman, J.S., Mills, A., 1987. Aqueous pyrite oxidation by dissolved oxygen and by ferric iron. Geochemica Cosmochima Acta 54, 1561-1572.

Nickson, R.T., McArthur, K.M., Ravenscroft, J.M., Burgess, W.G., Ahmed, K.M., 2000.

Mechanism of arsenic release to groundwater, Bangladesh and West Bengal. Applied

Geochemistry 15, 403-413.

O’Day, P.A., Vlassopoulos, D., Root, R., Rivera, N., 2004. The influence of sulfur and iron on dissolved arsenic concentrations in the shallow subsurface under changing redox conditions. Proceedings of the National Academy of Sciences 101 (38), 13703-13708.

Ostwald, J., England, B.M., 1977. Notes on framboidal pyrite from Allandale, New South Wales, Australia. Mineral. Deposita 12, 111-116.

Parkhurst, D.L., Appelo, C.A.J., 1999. User's guide to PHREEQC (Version 2) - A computer program for speciation, batch-reactions, one-dimensional transport, and inverse geochemical calculations. U.S. Department of Interior and U.S. Geological Survey, Denver, CO.

Pirajno, F., 2009. Hydrothermal Processes and Mineral Systems. Springer Science, The Netherlands.

Raven, K.P., Jain, A., Loeppert, R.H., 1998. Arsenite and arsenate adsorption on ferrihydrite: Kinetics, equilibrium and adsorption envelopes. Environmental Science and Technology 32, 344-349. 
Redman, A.D., Macalady, D.L., Ahmann, D., 2002. Natural organic matter affects arsenic speciation and sorption onto hematite. Environmental Science and Technology 36, 2889-2896.

Savage, K.S., Ashley, R.P., Bird, D.K., 2009. Geochemical evolution of a high arsenic, alkaline pit-lake in the Mother Lode Gold District, California. Economic Geology 104, 1171-1211.

Sengupta, A.K., 2002. Environmental Separation of Heavy Metals - Engineering Processes. Lewis Publishers, London.

Smedley, P.L., Kinniburgh, D.G., 2002. A review of the source, behavior and distribution of arsenic in natural waters. Applied Geochemistry 17, 517-568.

Smith, A.H., Hopenhayn-Rich, C., Bates, M.N., Goeden, H.M., Hertz-Picciotto, I., Duggan, H.M., Wood, R., Kosnett, M.J., Smith, M.T., 1992. Cancer risks from arsenic in drinking water. Environmental Health Perspectives 97, 259-267.

Stachowicz, M., Hiemstra, T., Van Riemsdijk, W.H., 2008. Multi-competitive interaction of $\mathrm{As}(\mathrm{III})$ and $\mathrm{As}(\mathrm{V})$ with $\mathrm{Ca}^{2+}, \mathrm{Mg}^{2+}, \mathrm{PO}_{4}{ }^{3-}$ and $\mathrm{CO}_{3}{ }^{2-}$ ions on goethite. Journal of Colloid and Interface Science 320, 400-414.

Tabelin, C.B., Igarashi, T., 2009. Mechanisms of arsenic and lead release from hydrothermally altered rock. Journal of Hazardous Materials 169, 980-990.

Tabelin, C.B., Igarashi, T., Tamoto, S., 2010. Factors affecting arsenic mobility from hydrothermally altered rock in impoundment-type in situ experiments. Minerals Engineering 23, 238-248.

Tabelin, C.B., Igarashi, T., Takahashi., R., 2012a.The roles of pyrite and calcite in the mobilization of arsenic and lead from hydrothermally altered rocks excavated in Hokkaido, Japan. Geochemical Exploration, http://dx.doi.org/10.1016/j.gexplo.2012.06.003 .

Tabelin, C.B., Igarashi, T., Takahashi., R., 2012b. Mobilization and speciation of arsenic from altered rock in laboratory column experiments under ambient conditions. Applied Geochemistry 27, 326-342.

Takahashi, T., Fujii, K., Igarashi, T., Kaketa, K., Yamada, N., 2011. Distribution properties and leaching of arsenic by the hydrothermally-altered rocks of Nakakoshi Area, central Hokkaido, Japan. Journal of the Japan Society of Engineering Geology 52(2), 46-54. (paper in Japanese with English abstract)

Tempel, R.N., Shevenell, L.A., Lechler, P., Price, J., 2000. Geochemical modeling approach to predicting arsenic concentrations in a mine pit lake. Applied Geochemistry 15, 475-492.

Todd, E.C., Sherman, D.M., Purton, J.A., 2003. Surface oxidation of pyrite under ambient atmospheric and aqueous ( $\mathrm{pH}=2$ to 10$)$ conditions: Electronic structure and mineralogy from $\mathrm{X}$ ray absorption spectroscopy. Geochim. Cosmochim. Acta 67(5), 881-893. 
Tseng, W.P., Chu, H.M., How, S.W., Fong, J.M., Lin, C.S., Yeh, S., 1968. Prevalence of skin cancer in an endemic area of chronic arsenicism in Taiwan. J. Natl. Cancer Inst. 40, 453-463.

Wang, S., Mulligan, C., 2006. Natural attenuation processes for remediation of arsenic contaminated soils and groundwater. Journal of Hazardous Materials 138(3), 459-470.

Wilkie, J.A., Hering, J.G., 1996. Adsorption of arsenic onto hydrous ferric oxide: Effects of adsorbate/adsorbent ratios and co-occurring solutes. Colloid Surface A 107, 97-110.

Zaldivar, R., 1974. Arsenic contanination of drinking water and food-stuffs causing endemic chronic poisoning. Beitr. Pathol. 151, 384-400.

Zhu, Y.N., Zhang, X.H., Xie, Q.L., Wang, D.Q., Cheng, G.W., 2006. Solubility and stability of calcium arsenates at $25^{\circ} \mathrm{C}$. Water, Air, \& Soil Pollution 169, 221-238. 


\section{Figure Captions}

FIGURE 1 Evolution of total As, arsenite (As[III]), $\mathrm{pH}$ and Eh with time in the batch experiments under anoxic condition: (a) solid-liquid ratio $=1: 5$, (b) solid-liquid ratio $=1: 10,(\mathrm{c}) \mathrm{pH}$ change with time, and (d) Eh change with time.

FIGURE 2 Effects of infiltration rate on the $\mathrm{PV}, \mathrm{pH}, \mathrm{Eh}, \mathrm{As}, \mathrm{EC}, \mathrm{Ca}^{2+}, \mathrm{SO}_{4}{ }^{2-}$ and $\mathrm{Fe}$ under anoxic condition; (a) PV change with time, (b) pH change with time, (c) Eh change with time, (d) As concentration change with time, (e) EC change with time, (f) $\mathrm{Ca}^{2+}$ concentration change with time, (g) $\mathrm{SO}_{4}{ }^{2-}$ concentration change with time, and (h) Fe concentration change with PV.

FIGURE 3 Correlation between As and $\mathrm{Ca}^{2+}$ concentrations in the effluents of all cases. Correlation coefficients of cases 1-, 2- and 3-anoxic for $\mathrm{N}>50$ are equal to $0.97,0.93$ and 0.92 , respectively. All of these values are statistically significant at $\mathrm{p}<0.005$.

FIGURE 4 Effects of anoxic conditions on the $\mathrm{pH}$, Eh, $\mathrm{As}, \mathrm{Ca}^{2+}, \mathrm{SO}_{4}{ }^{2-}$ and $\mathrm{Fe}$; (a) $\mathrm{pH}$ change with time, (b) Eh change with time, (c) As concentration change with time, (d) $\mathrm{Ca}^{2+}$ concentration change with time, (e) $\mathrm{SO}_{4}{ }^{2-}$ concentration change with time, and (f) Fe concentration change with time.

FIGURE 5 Results of the tracer and spike tests under anoxic condition; (a) $\mathrm{Br}^{-}$ concentration with dimensionless time $\left(t / t_{\text {mean }}\right)$, and (b) As concentration before and after the spike test.

FIGURE 6 Spatial distribution of As in the pore water of all cases.

FIGURE $7 \mathrm{Eh}-\mathrm{pH}$ predominance diagram of As at $25^{\circ} \mathrm{C}, 1.013$ bars, activity $\mathrm{As}=10^{-6}$, activity $\mathrm{SO}_{4}{ }^{2-}=10^{-3}$. The rectangular regions represent the range of $\mathrm{Eh}$ and $\mathrm{pH}$ of the actual effluents collected in cases 2- and 3-anoxic.

FIGURE 8 Evolution of total As, arsenate (As[V]) and arsenite (As[III]) concentrations with time in the effluent: (a) case 2-anoxic and (b) case 3-anoxic.

FIGURE 9 Evolution of total As, arsenate (As[V]) and arsenite (As[III]) concentrations with depth in case 2-anoxic.

FIGURE 10A SEM observation (a) and elemental maps of $\mathrm{Si}$ (b), $\mathrm{Al}$ (c), Fe (d), S (e), and O (f) at a magnification of $50 \mu \mathrm{m}$ from altered rock collected in the bottom part of case 2-anoxic after the column experiments.

FIGURE 10B SEM observation (a) and elemental maps of $\mathrm{Si}$ (b), $\mathrm{Al}$ (c), $\mathrm{Mg}$ (d), $\mathrm{Fe}(\mathrm{e})$, and $\mathrm{O}$ (f) at a magnification of $50 \mu \mathrm{m}$ from altered rock collected in the bottom part of case 2-anoxic after the column experiments. 
FIGURE 11 Saturation indices of $\mathrm{Fe}$ and $\mathrm{Al}$ oxides/oxyhydroxides, gypsum, calcite and calcium arsenates with time: (a) case 2-anoxic and (b) case 3-anoxic. 
(a)

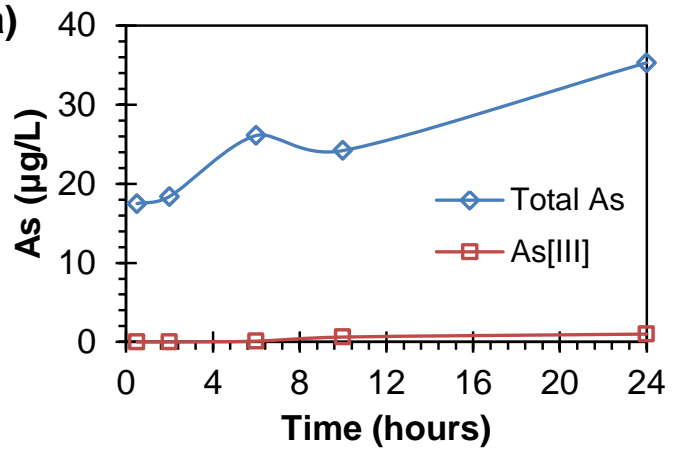

(c) 11

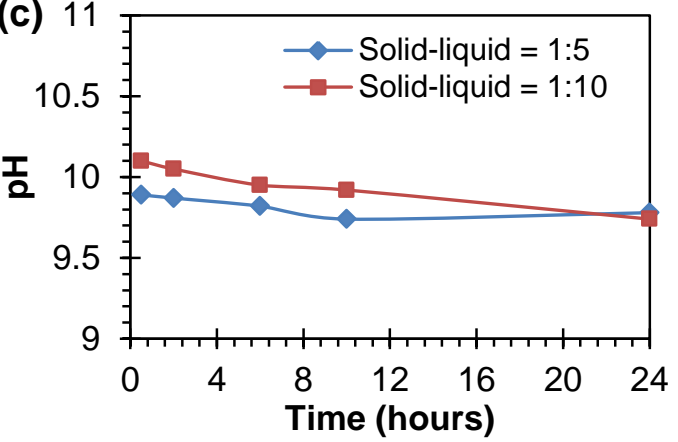

(b)
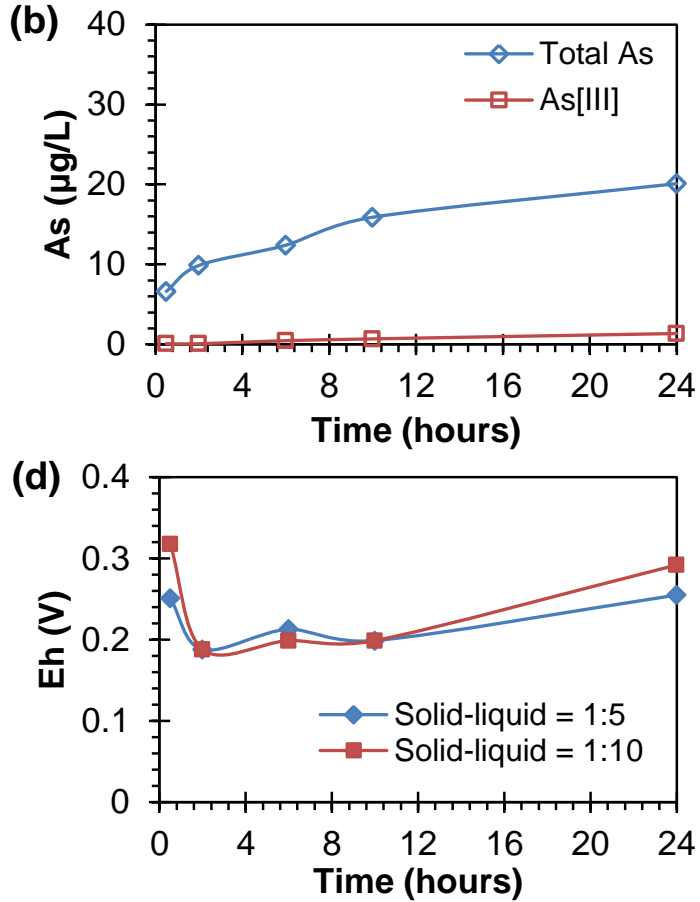

Figure 1 
(a)

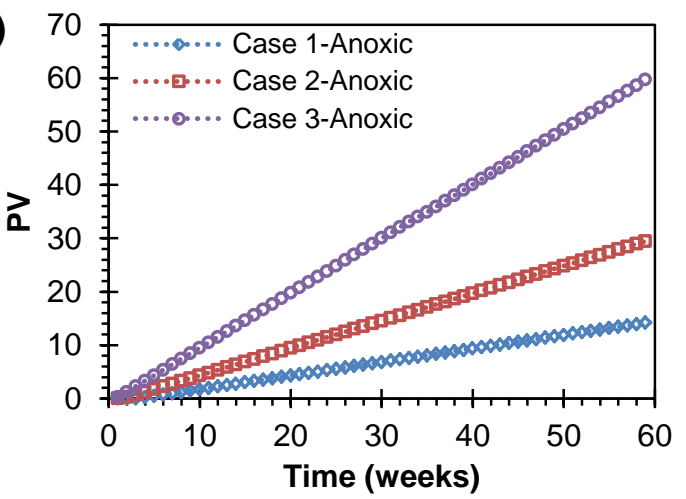

(c)
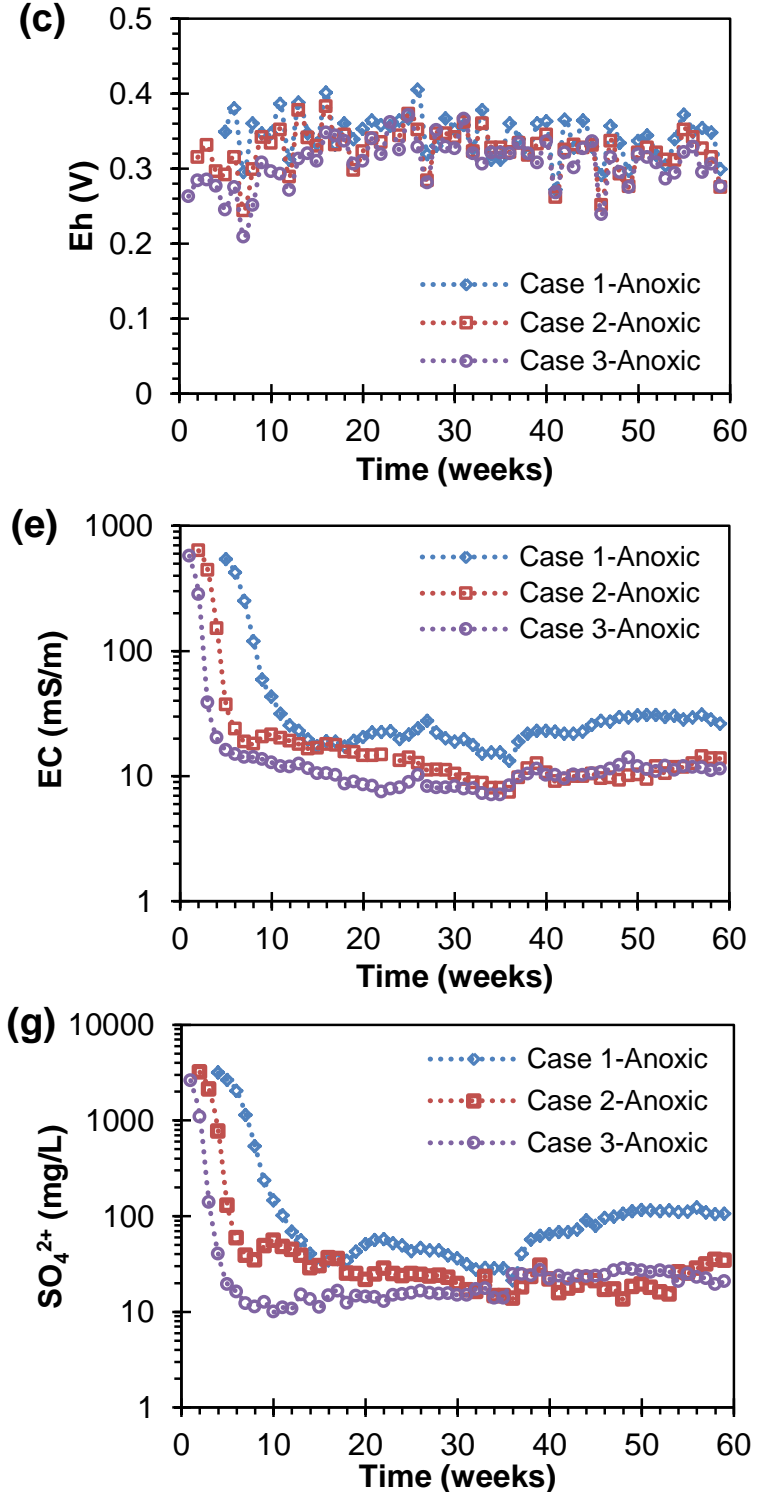
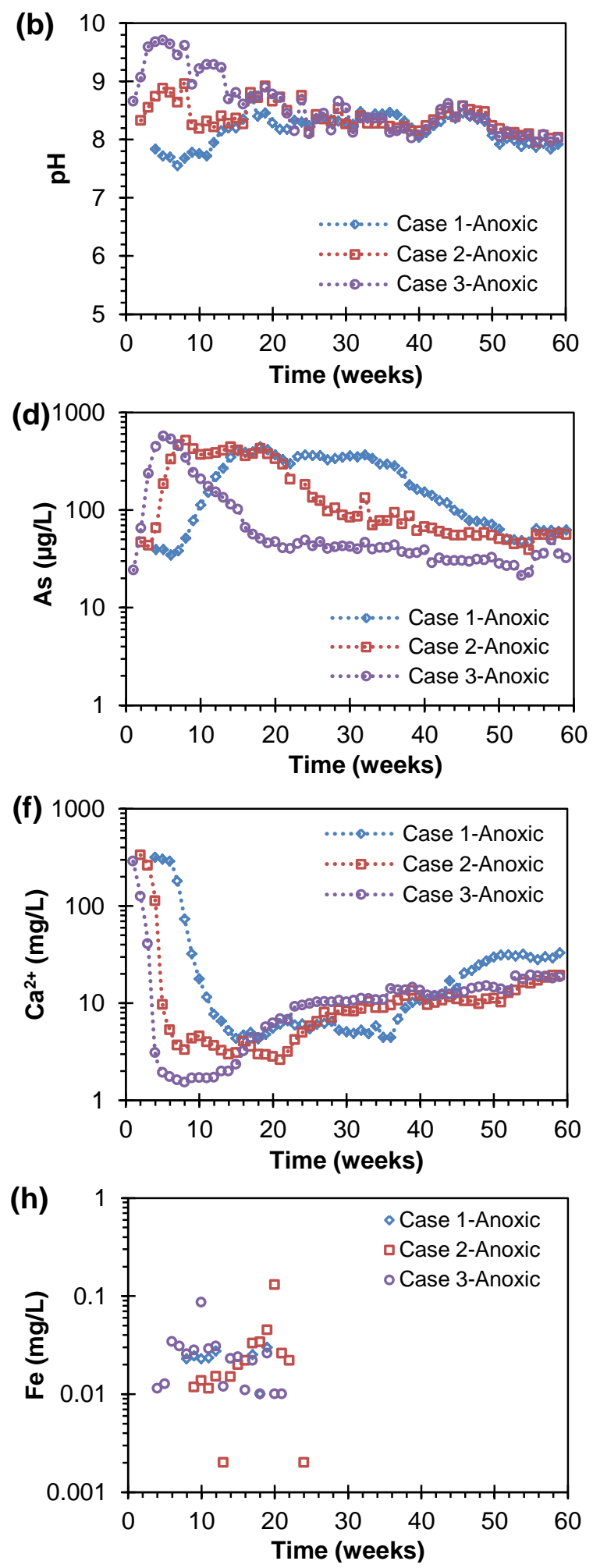

Figure 2 


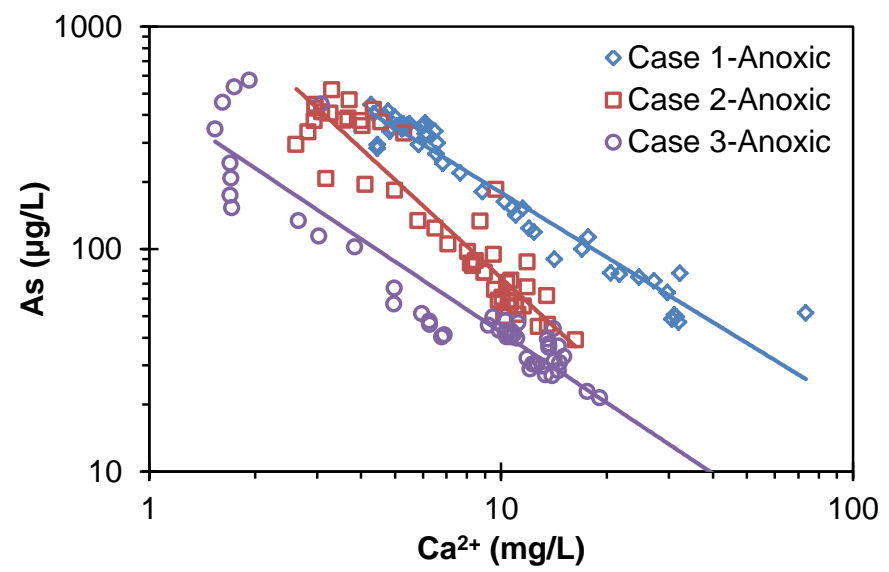

Figure 3 

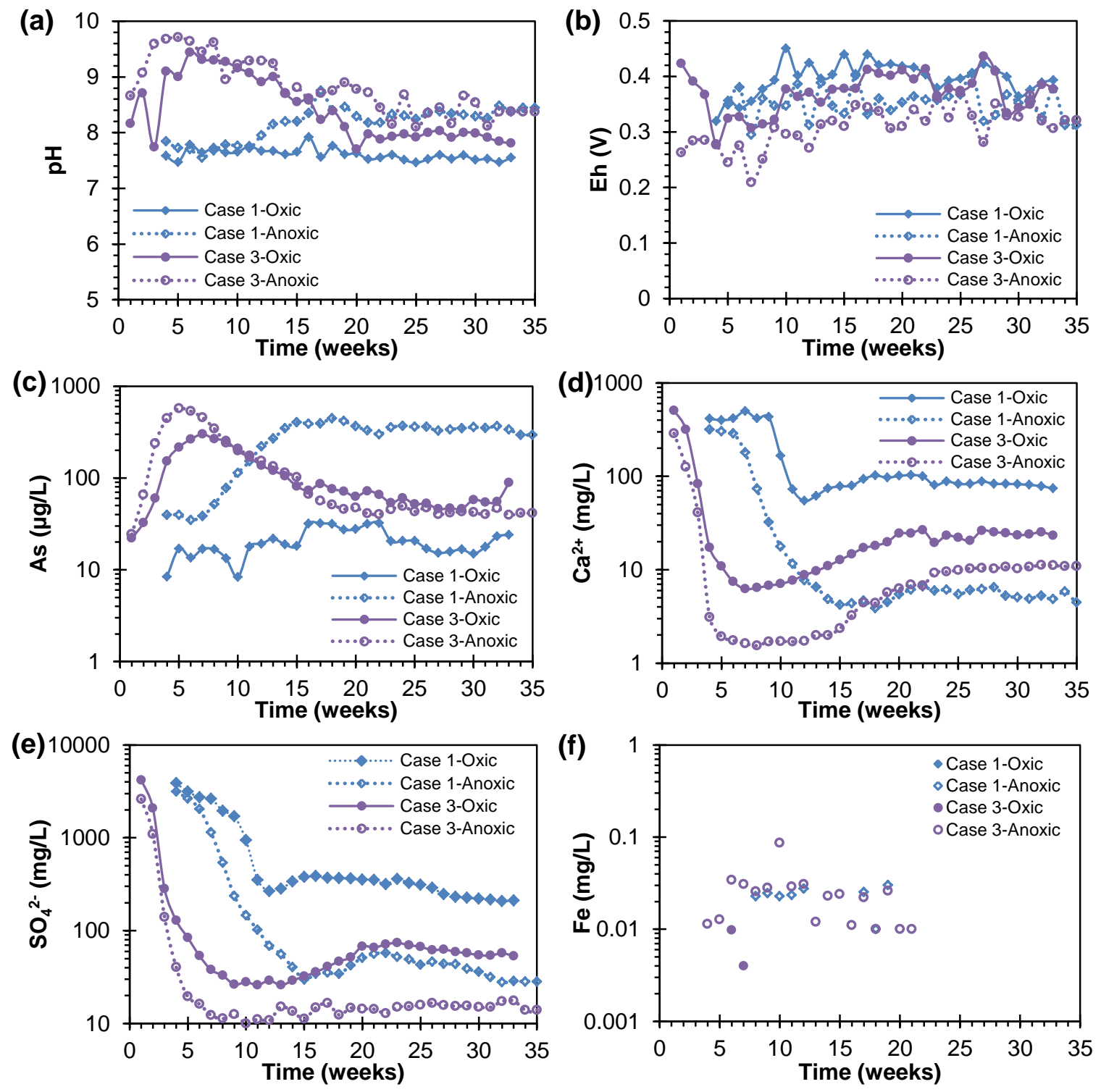

Figure 4 

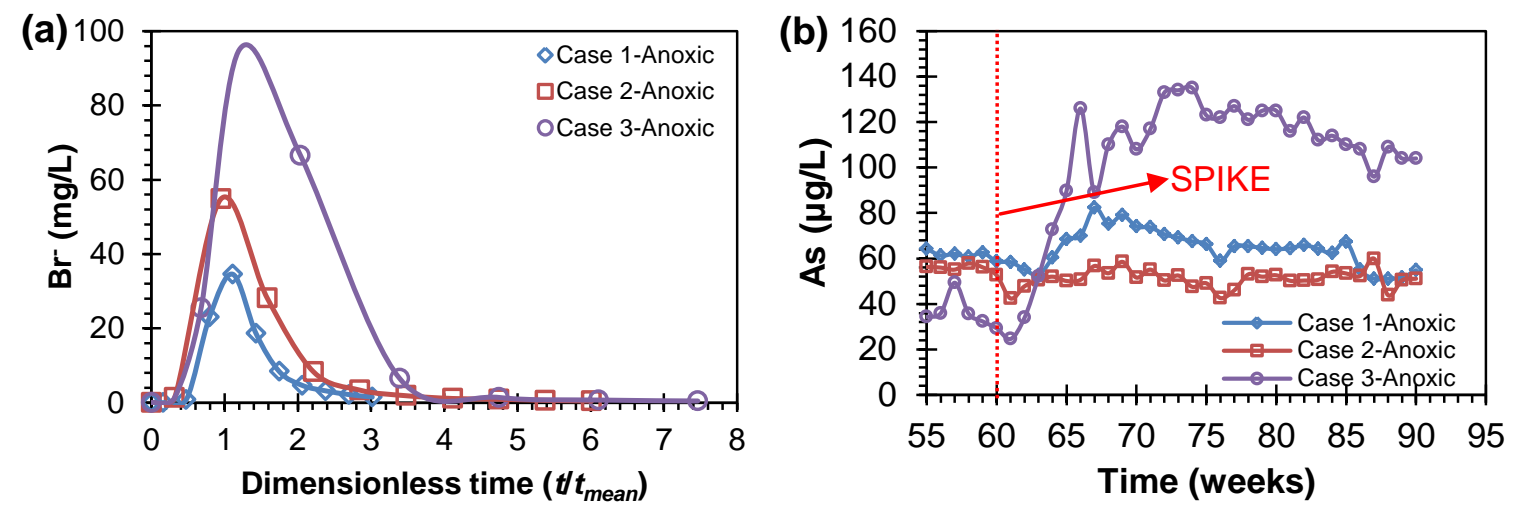

Figure 5

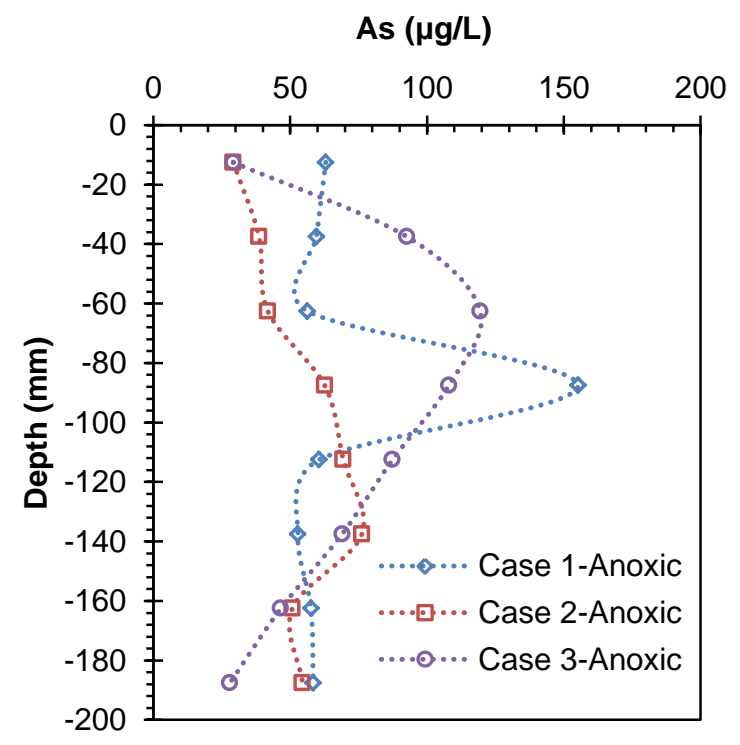

Figure 6 


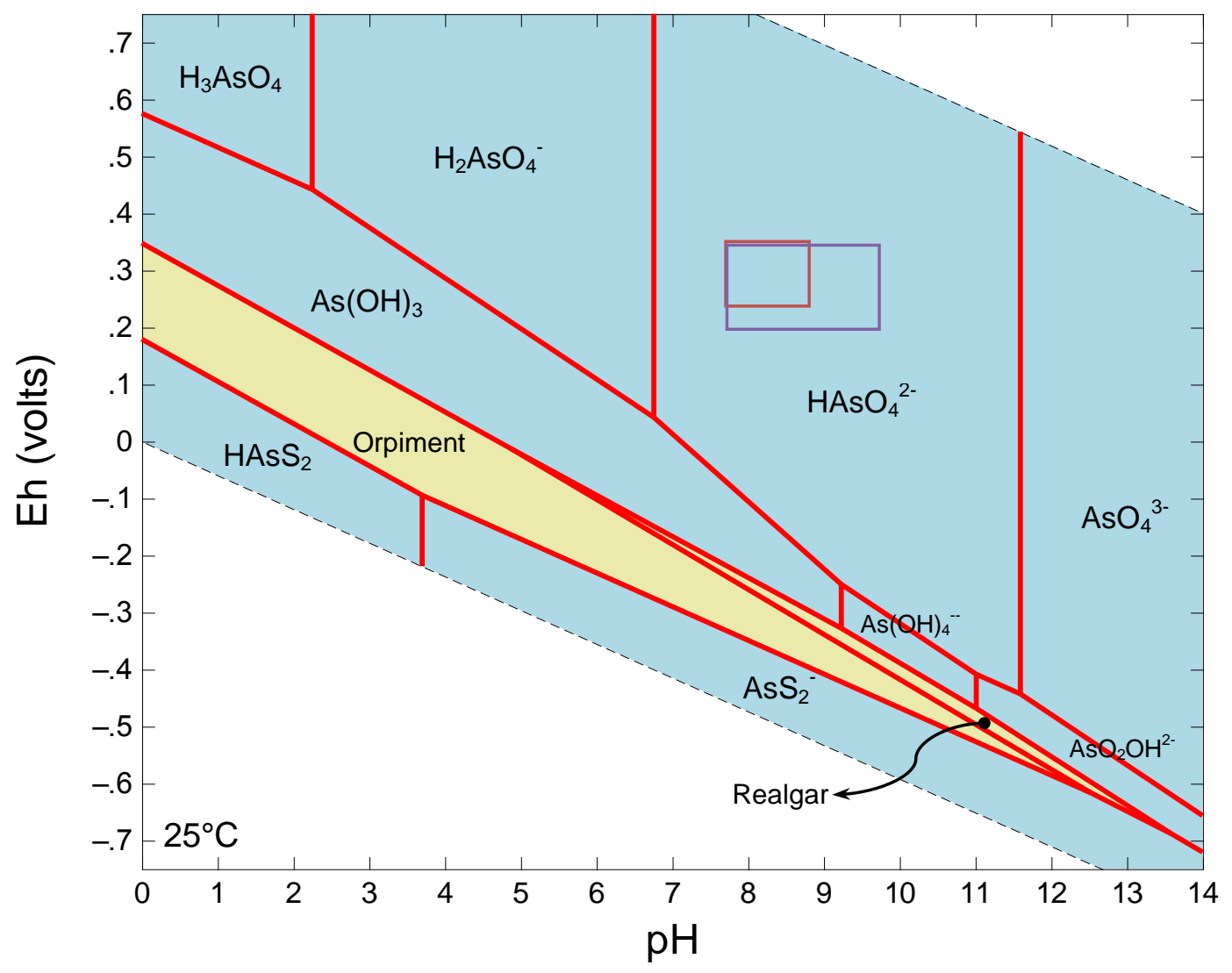

Case 2-

Anoxic

Case 3-

Anoxic

Figure 7

(a)

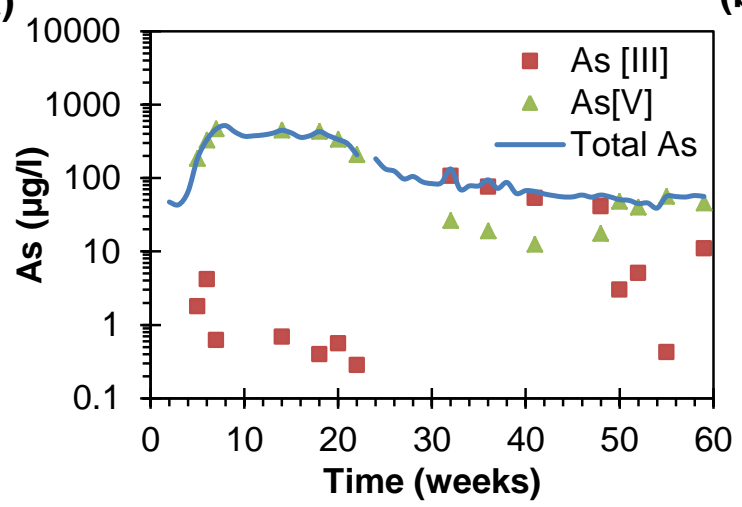

(b)

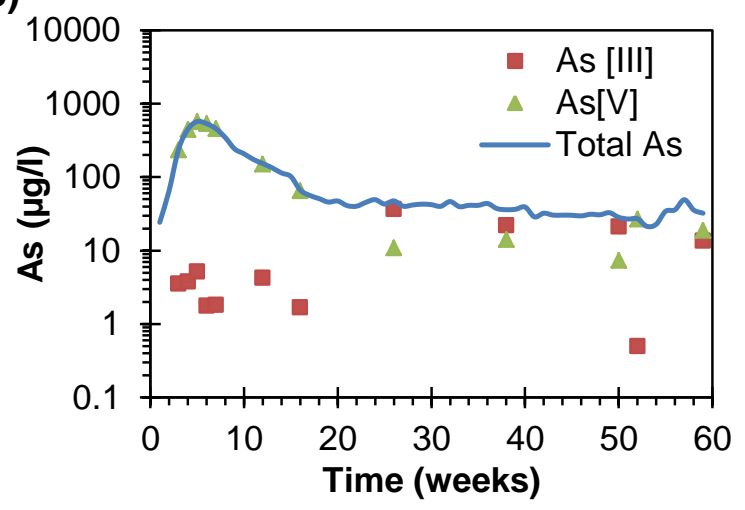

Figure 8 


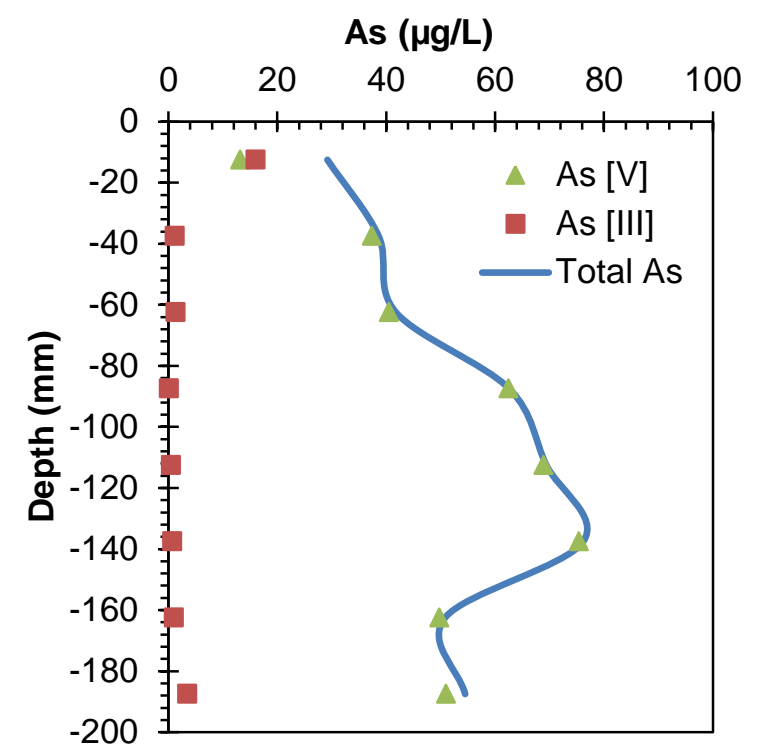

Figure 9

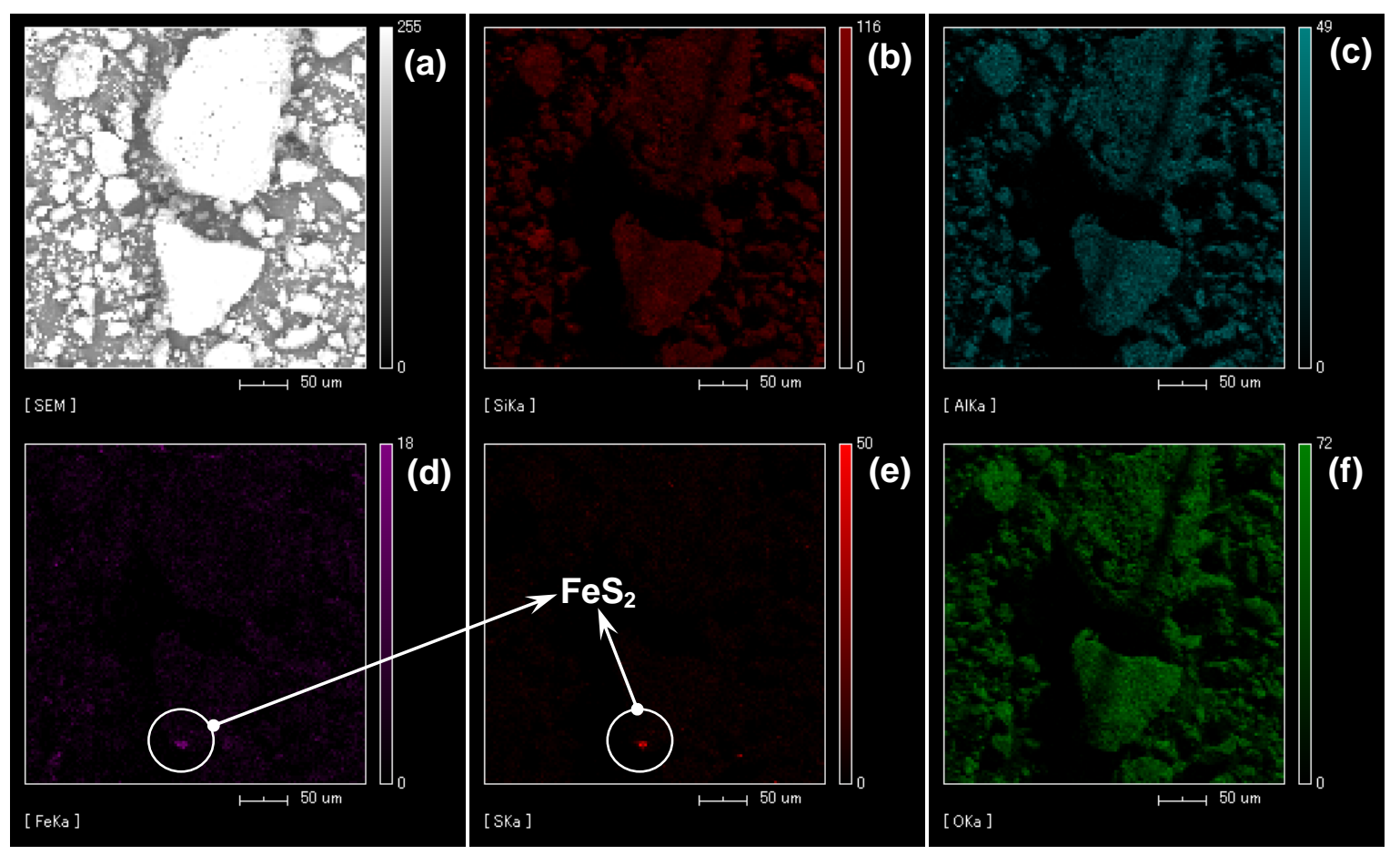

Figure 10A 

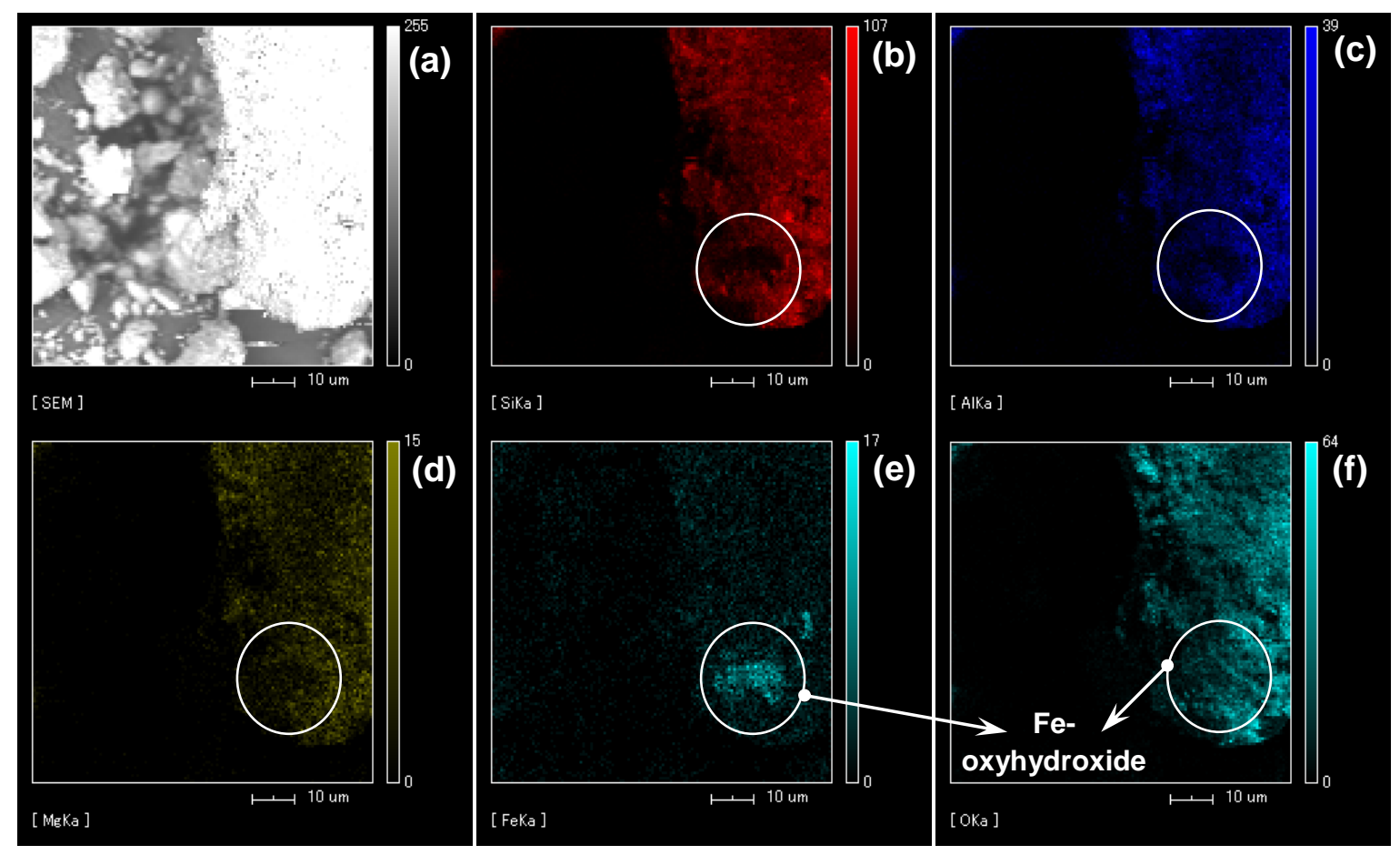

Figure 10B
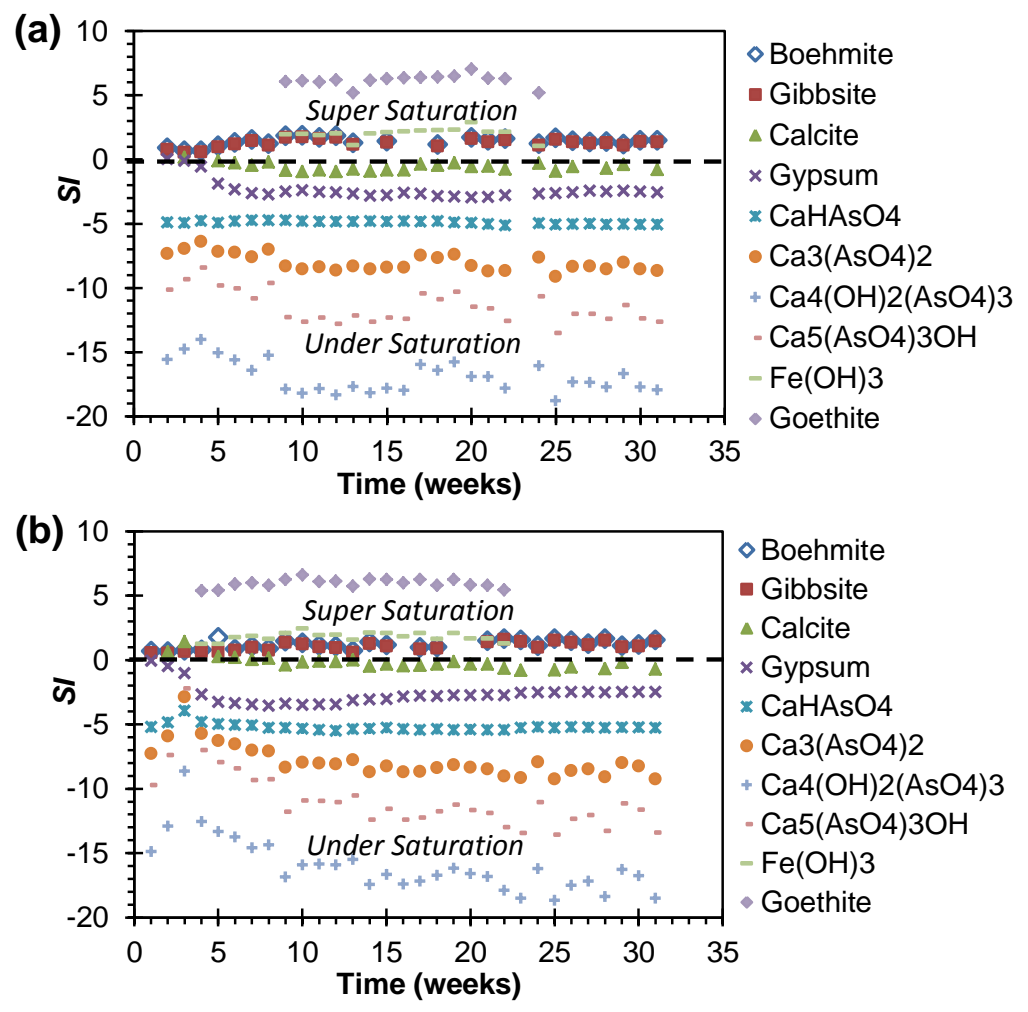

Figure 11 
Table 1. List of column experimental conditions

\begin{tabular}{cccccccccc}
\hline $\begin{array}{c}\text { Column } \\
\text { name }\end{array}$ & $\begin{array}{c}\text { Infiltration } \\
\text { rate } \\
(\mathrm{mm} / \text { week })\end{array}$ & $\begin{array}{c}\text { Thickness of } \\
\text { rock bed } \\
(\mathrm{mm})\end{array}$ & $\begin{array}{c}\text { Bulk } \\
\text { density } \\
\left(\mathrm{g} / \mathrm{cm}^{3}\right)\end{array}$ & $\begin{array}{c}\text { Mass } \\
\text { rock } \\
(\mathrm{g})\end{array}$ & $\begin{array}{c}\text { Porosity } \\
(\%)\end{array}$ & $\begin{array}{c}\text { PV } \\
\text { Initial } \\
\left(\mathrm{cm}^{3}\right)\end{array}$ & $\begin{array}{c}\text { PV after } \\
\text { infiltration } \\
\left(\mathrm{cm}^{3}\right)\end{array}$ & $\begin{array}{c}\text { Tracer } \\
\text { test }\end{array}$ & $\begin{array}{c}\text { Spike } \\
\text { Test }\end{array}$ \\
\hline $\begin{array}{c}\text { Case 1- } \\
\text { Anoxic }\end{array}$ & 20 & 200 & 1.62 & 688 & 40.7 & 173.9 & 163.4 & Yes & As[III] \\
$\begin{array}{c}\text { Case 2- } \\
\begin{array}{c}\text { Anoxic } \\
\text { Case 3- } \\
\text { Anoxic }\end{array}\end{array}$ & 40 & 200 & 1.62 & 688 & 40.7 & 173.9 & 163.4 & Yes & As[V] \\
\hline
\end{tabular}

Table 2. Properties of the column influents after the removal of dissolved $\mathrm{O}_{2}$ and $\mathrm{CO}_{2}$

\begin{tabular}{ccccccc}
\hline Solution & $\mathrm{pH}$ & $\begin{array}{c}\mathrm{Eh} \\
(\mathrm{V})\end{array}$ & $\begin{array}{c}\mathrm{DO} \\
(\mathrm{mg} / \mathrm{L})\end{array}$ & $\begin{array}{c}\mathrm{As}[\mathrm{III}] \\
(\mathrm{mg} / \mathrm{L})\end{array}$ & $\begin{array}{c}\mathrm{As}[\mathrm{V}] \\
(\mathrm{mg} / \mathrm{L})\end{array}$ & $\begin{array}{c}\mathrm{Br}^{-} \\
(\mathrm{mg} / \mathrm{L})\end{array}$ \\
\hline Deionized water & 7.42 & 0.354 & $0.1-0.3$ & - & - & - \\
Spike and tracer solution 1 & 7.50 & 0.289 & 0.1 & - & 9.80 & 99.5 \\
Spike and tracer solution 2 & 6.35 & 0.457 & 0.1 & 9.84 & - & 99.7 \\
\hline
\end{tabular}

Table 3. Water balances in the columns until week 59

\begin{tabular}{cccc}
\hline Column & $\begin{array}{c}\text { Total volume of } \\
\text { influent }(\mathrm{ml})\end{array}$ & $\begin{array}{c}\text { Total volume of } \\
\text { effluent }(\mathrm{ml})\end{array}$ & $\begin{array}{c}\text { Total volume retained } \\
\text { and lost }(\mathrm{ml})\end{array}$ \\
\hline Case 1-anoxic & $2,507.5$ & $2,319.5$ & 188 \\
Case 2-anoxic & 5,015 & $4,814.9$ & 200.1 \\
Case 3-anoxic & 10,030 & $9,750.3$ & 279.7 \\
\hline
\end{tabular}

Table 4. Mass balances of As, $\mathrm{Ca}^{2+}$ and $\mathrm{SO}_{4}{ }^{2-}$ in case 1-anoxic from PV $0-14$

\begin{tabular}{ccccc}
\hline $\begin{array}{c}\text { Chemical } \\
\text { name }\end{array}$ & $\begin{array}{c}\text { Total mass } \\
(\mathrm{mg})\end{array}$ & $\begin{array}{c}\text { Contribution } \\
\text { of calcite }(\mathrm{mg})\end{array}$ & $\begin{array}{c}\text { Contribution } \\
\text { of pyrite }(\mathrm{mg})\end{array}$ & $\begin{array}{c}\text { Contribution of } \\
\text { soluble phases } \\
(\mathrm{mg})\end{array}$ \\
\hline $\mathrm{As}$ & $0.470^{*}$ & - & 0.138 & 0.332 \\
$\mathrm{Ca}^{2+}$ & $76.8^{*}$ & 30.8 & - & 46 \\
$\mathrm{SO}_{4}{ }^{2-}$ & $542^{*}$ & - & 153 & 389 \\
\hline
\end{tabular}

Note: "-": negligible; "*": measured 
Table 5. Mass balances of As, $\mathrm{Ca}^{2+}$ and $\mathrm{SO}_{4}{ }^{2-}$ in case 2-anoxic from PV $0-14$

\begin{tabular}{ccccc}
\hline $\begin{array}{c}\text { Chemical } \\
\text { name }\end{array}$ & $\begin{array}{c}\text { Total mass } \\
(\mathrm{mg})\end{array}$ & $\begin{array}{c}\text { Contribution } \\
\text { of calcite }(\mathrm{mg})\end{array}$ & $\begin{array}{c}\text { Contribution } \\
\text { of pyrite }(\mathrm{mg})\end{array}$ & $\begin{array}{c}\text { Contribution of } \\
\text { soluble phases } \\
(\mathrm{mg})\end{array}$ \\
\hline $\mathrm{As}$ & $0.647^{*}$ & - & 0.124 & 0.523 \\
$\mathrm{Ca}^{2+}$ & $54.7^{*}$ & 11.7 & - & 44.4 \\
$\mathrm{SO}_{4}{ }^{2-}$ & $449^{*}$ & - & 72 & 389 \\
\hline
\end{tabular}

Note: "-": negligible; "*": measured

Table 6. Mass balances of As, $\mathrm{Ca}^{2+}$ and $\mathrm{SO}_{4}^{2-}$ in case 3-anoxic from PV $0-14$

\begin{tabular}{ccccc}
\hline $\begin{array}{c}\text { Chemical } \\
\text { name }\end{array}$ & $\begin{array}{c}\text { Total mass } \\
(\mathrm{mg})\end{array}$ & $\begin{array}{c}\text { Contribution } \\
\text { of calcite }(\mathrm{mg})\end{array}$ & $\begin{array}{c}\text { Contribution } \\
\text { of pyrite }(\mathrm{mg})\end{array}$ & $\begin{array}{c}\text { Contribution of } \\
\text { soluble phases } \\
(\mathrm{mg})\end{array}$ \\
\hline $\mathrm{As}$ & $0.634^{*}$ & - & 0.103 & 0.531 \\
$\mathrm{Ca}^{2+}$ & $51.1^{*}$ & 7.24 & - & 43.9 \\
$\mathrm{SO}_{4}{ }^{2-}$ & $343^{*}$ & - & 38 & 305 \\
\hline
\end{tabular}

Note: "-": negligible; "*": measured

Table 7. Mass balance of As during the spike tests

\begin{tabular}{ccccc}
\hline $\begin{array}{c}\text { Column } \\
\text { notation }\end{array}$ & $\begin{array}{c}\text { Mass of As } \\
\text { leached from } \\
\text { rock (mg) }\end{array}$ & $\begin{array}{c}\text { Mass of As } \\
\text { spiked (mg) }\end{array}$ & $\begin{array}{c}\text { Mass of As } \\
\text { retained } \\
(\mathrm{mg})\end{array}$ & $\begin{array}{c}\text { Total Mass } \\
\text { of As } \\
\text { leached (mg) }\end{array}$ \\
\hline Case 1-anoxic & 0.073 & $0.418^{*}$ & 0.412 & $0.079^{*}$ \\
Case 2-anoxic & 0.128 & $0.833^{*}$ & 0.833 & $0.128^{*}$ \\
Case 3-anoxic & 0.17 & $1.67^{*}$ & 1.32 & $0.523^{*}$ \\
\hline
\end{tabular}

*: measured value

Table 8. Simulated $\mathrm{pH}, \mathrm{Ca}^{2+}$ and $\mathrm{SO}_{4}{ }^{2-}$ concentrations in a calcite-pyrite system under equilibrium conditions and measured values in anoxic column experiments.

\begin{tabular}{|c|c|c|c|c|c|c|}
\hline \multirow[t]{2}{*}{ Parameters } & \multirow{2}{*}{\multicolumn{3}{|c|}{ Simulated }} & \multicolumn{3}{|c|}{$\begin{array}{c}\text { Measured } \\
\text { (average values: week } 25-59 \text { ) }\end{array}$} \\
\hline & & & & Case 1 & Case 2 & Case 3 \\
\hline $\mathrm{O}_{2}(\mathrm{mg} / \mathrm{L})$ & 1 & 0.5 & 0 & - & - & - \\
\hline $\mathrm{CO}_{2}(\mathrm{mg} / \mathrm{L})$ & 1 & 0.5 & 0 & - & - & - \\
\hline $\mathrm{pH}$ & 8.16 & 8.65 & 9.91 & 8.22 & 8.27 & 8.25 \\
\hline $\mathrm{Ca}^{2+}(\mathrm{mol} / \mathrm{L})$ & $4.57 \times 10^{-4}$ & $2.64 \times 10^{-4}$ & $1.17 \times 10^{-4}$ & $3.15 \times 10^{-4}$ & $2.82 \times 10^{-4}$ & $3.37 \times 10^{-4}$ \\
\hline $\mathrm{SO}_{4}{ }^{2-}(\mathrm{mol} / \mathrm{L})$ & $2.67 \times 10^{-4}$ & $1.37 \times 10^{-4}$ & $3.18 \times 10^{-8}$ & $6.19 \times 10^{-4}$ & $2.24 \times 10^{-4}$ & $2.22 \times 10^{-4}$ \\
\hline $\mathrm{Ca}^{2+} / \mathrm{SO}_{4}{ }^{2-}$ & 1.71 & 1.93 & 3679 & 0.51 & 1.26 & 1.52 \\
\hline
\end{tabular}

